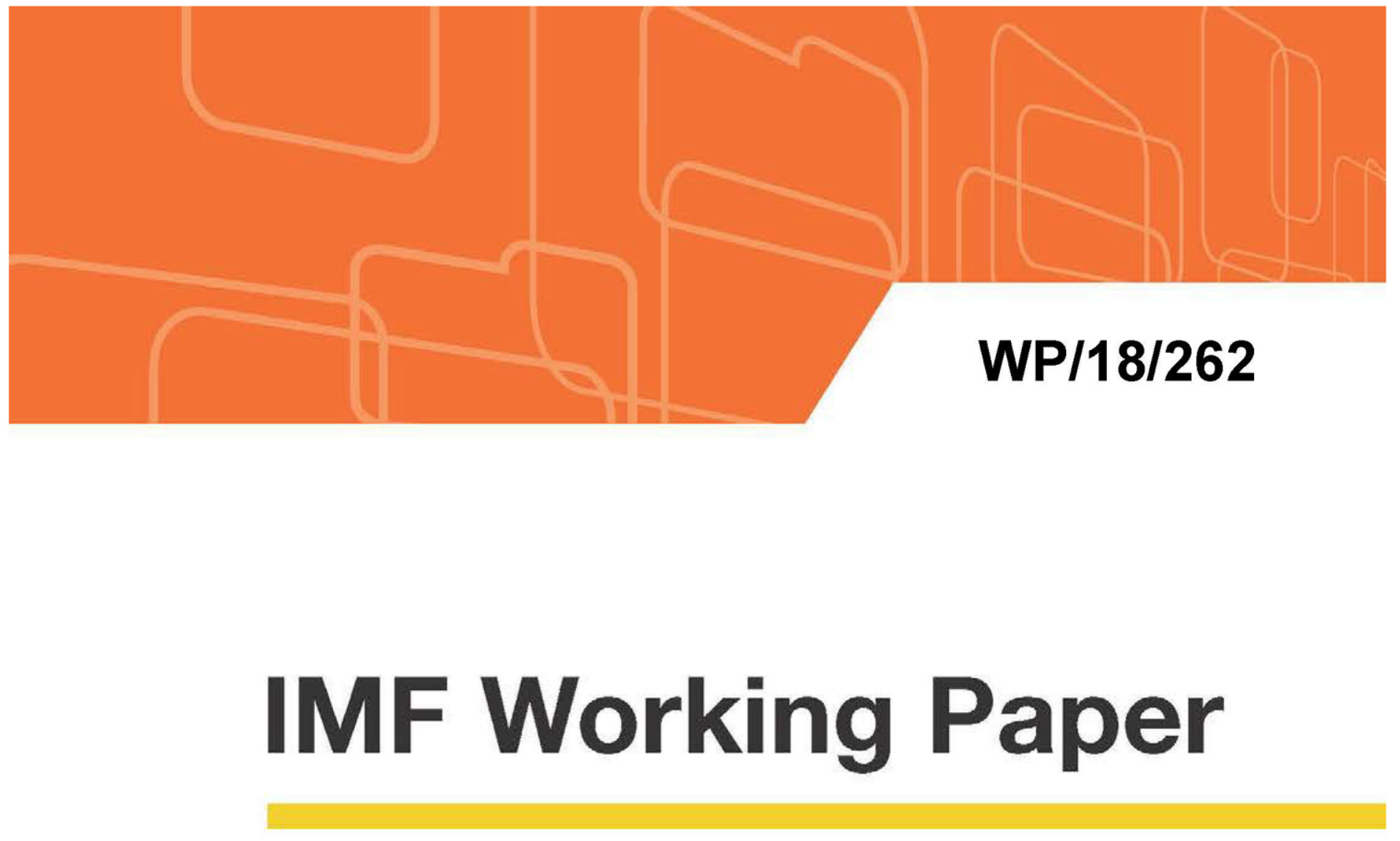

\title{
The Rise in Corporate Saving and Cash Holding in Advanced Economies: Aggregate and Firm Level Trends
}

by Mai Chi Dao and Chiara Maggi

IMF Working Papers describe research in progress by the author(s) and are published to elicit comments and to encourage debate. The views expressed in IMF Working Papers are those of the author(s) and do not necessarily represent the views of the IMF, its Executive Board, or IMF management. 


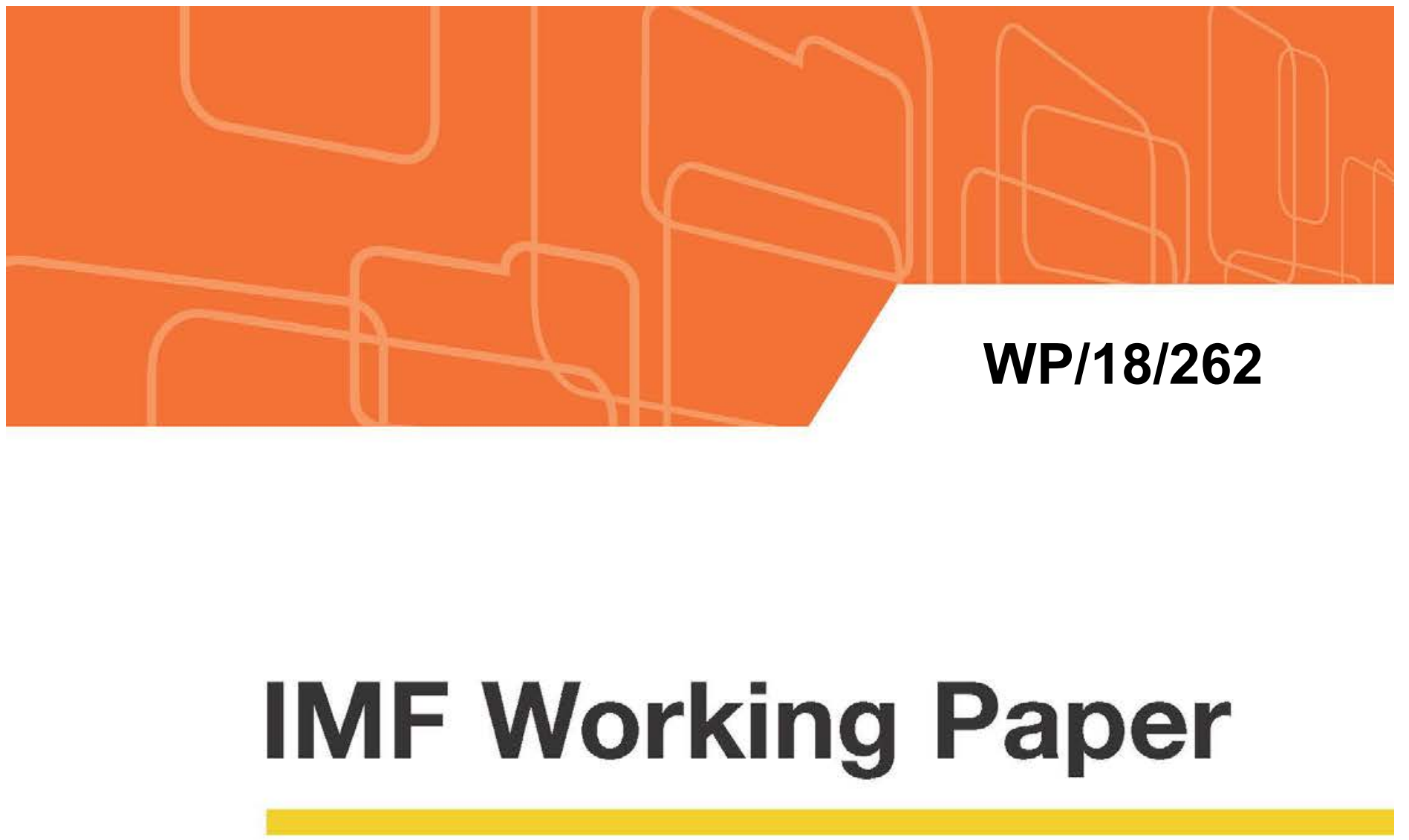

\section{The Rise in Corporate Saving and Cash Holding in Advanced Economies: Aggregate and Firm Level Trends}

by Mai Chi Dao and Chiara Maggi

IMF Working Papers describe research in progress by the author(s) and are published to elicit comments and to encourage debate. The views expressed in IMF Working Papers are those of the author(s) and do not necessarily represent the views of the IMF, its Executive Board, or IMF management.

$$
\text { I N T E R N A T I O N A L M O N E T A R Y F U N D }
$$




\title{
IMF Working Paper
}

\author{
Research Department
}

\section{The Rise in Corporate Saving and Cash Holding in Advanced Economies: Aggregate and Firm Level Trends}

\section{Prepared by Mai Chi Dao and Chiara Maggi ${ }^{1}$}

Authorized for distribution by Luis Cubeddu

November 2018

\section{IMF Working Papers describe research in progress by the author(s) and are published to elicit comments and to encourage debate. The views expressed in IMF Working Papers are those of the author(s) and do not necessarily represent the views of the IMF, its Executive Board, or IMF management.}

\begin{abstract}
Using cross-country national accounts and firm-level data, we document a broad-based trend in rising gross saving and net lending of non-financial corporates across major industrialized countries over the last two decades, though most pronounced in countries with persistent current account surpluses. We find that this trend holds consistently across major industries, and is concentrated among large firms, driven by rising profitability, lower financing costs, and reduced tax rates. At the same time, higher gross corporate saving have not supported a commensurate increase in fixed capital investment, but instead led to a build-up of liquid financial assets (cash). The determinants of corporate cash holding and saving are also broadbased across countries, with the growth in assets of large firms, R\&D intensity, and lower effective tax rates accounting for most of the increase over the last 15 years.
\end{abstract}

JEL Classification Numbers: G31, F12, O32

Keywords: Cash holding, R\&D, corporate saving, current account surplus

Authors' E-Mail Addresses: mdao@,imf.org; chiaramaggi2018@u.northwestern.edu

\footnotetext{
${ }^{1}$ Economics Department. Northwestern University. We are grateful to Helge Berger, Nigel Chalk, Luis Cubeddu, Pierre-Olivier Gourinchas, Camelia Minoiu, Gabriel Zucman and seminar participants at the IMF, Bank of England, and Bank of France for very helpful comments. We thank Deepali Gautam for excellent research assistance.
} 


\section{Introduction}

The role of the non-financial corporate sector in driving various aggregate structural trends such as the decline in labor income shares (see Autor et al. (2017); Chen et al. (2017)), higher average mark-ups and profit shares (De Loecker and Eeckhout (2017); Barkai (2016)), and declining investment and productivity growth (Gutiérrez and Philippon (2017)) has been gaining increased attention in the literature. Meanwhile in policy circles, there is mounting interest in understanding the corporate sector's role in driving the increase and persistence of current account surpluses of some countries (IMF (2017)). That said, we still lack a systematic analysis of the macro and micro level trends in corporate profits, saving and investment, and the vast majority of studies have so far focused on the behavior of corporate saving and investment in the US, posing the question of whether the identified patterns and mechanisms hold across a wider set of countries.

This paper fills the gap by documenting and analyzing the evolution of corporate saving-investment balances in major advanced economies starting from the mid 1990s. We contribute to the literature and policy debate by providing an in-depth look at the sources and uses of corporate saving, extending the analysis beyond the US to a sample covering nine $(\mathrm{G} 7+2)$ major advanced economies where reliable national accounts and firm level data are available (US, UK, Canada, France, Germany, Italy, Japan, Korea, the Netherlands). We combine both flow of funds and sectoral balance sheet data from national accounts with firm-level income statements and balance sheets data to arrive at a consistent view of the main trends and drivers.

First, using national accounts data, we document that the corporate sector swung from being a net borrower of funds from the rest of the economy to a net lender starting in the early 2000s across advanced economies, and study the extent to which this has been driven by rising gross saving or declining investment. Second, we decompose the change in corporate saving into contributions from the different sources: firms' profitability, property income, interest payments, tax payments, and shareholder payout. The secular increase in corporate gross saving across major advanced economies

2

CInternational Monetary Fund. Not for Redistribution 
has been accompanied by stagnating or declining investment in physical capital. Saving in excess of investment in physical capital is reflected in an increase in net lending (i.e. excess saving) of the corporate sector with respect to the rest of the economy. We therefore investigate the uses that firms make of these excess saving. We do so by looking at aggregate balance-sheet data of the non-financial corporate sector to shed light on how excess saving are allocated across different financial assets. Finally, we drill down to firm-level balance-sheet data to analyze the micro characteristics of firms driving the macro dynamics of corporate saving observed in aggregate data.

We document several empirical facts using sectoral balance sheet and flow of funds data. First, we find that the rise in corporate excess saving, in other words the trend towards a net lending position to the rest of the economy, is broadly common to all corporate sectors across our sample of major advanced economies, but is most pronounced in countries with persistent current account surpluses. Second, the increase in gross corporate saving mostly come from a combination of higher profitability and lower interest payments that have not been matched by higher taxes and dividends. Third, the analysis of aggregate balance sheets for non-financial corporations in each country reveals that these excess saving have been most consistently stored in very liquid assets, such as currency, deposits and short-term debt.

Importantly, we find a robust co-movement between national accounts and firmlevel data, which come from the Thompson Reuters Worldscope database and mainly draw from balance sheets data and income accounts of large, listed firms. This suggest that the saving-investment behavior of large corporations track well the aggregate corporate net lending trends from national accounts, and that studying the saving behavior of large public firms allows us to gain important insights into aggregate trends. Several important results emerge from firm-level data. First, we find that the rise in corporate net lending and cash holding is driven to a large extent by trends withinfirms rather than compositional changes. That is, higher average and aggregate net lending and cash ratios are primarily a result of higher propensity to retain earnings and hold cash by a typical large firm, rather than due to compositional shifts where low saving/low cash firms exit and/or high saving/high cash firms enter the sample. 
Second, we identify at the micro-level the characteristics of firms with the greatest propensity to hold liquid assets and retain earnings. Consistent with the correlation between firms' excess saving and liquid assets holding, we find that determinants of cash-holding also explain most of the variation in net lending within and across firms. Among the most robust and material determinants of higher corporate net lending within firms over time are rising profits and asset size, lower effective tax rates, and especially until the early 2000's, increasing spending on $R \& D$.

While our paper does not pin down fundamental causes for the rise in corporate saving, the detailed patterns documented point to important macroeconomic implications of the increasing dominance of large firms (see 2018 Jackson Hole conference). Firms that save much more than they invest tend to be larger and more profitable, engage strongly in $R \& D$ and have low effective tax rates as they are more likely to exploit complex international tax strategies. Therefore, the recently documented rise in industrial concentration is thus likely to have contributed to the trend in rising corporate saving (see Dao et al. (2018)). The detailed documentation of cross-country and sectoral corporate saving-investment trends should help shed further light into better understanding the shifts and persistence of aggregate flow of funds and external balances in key economies, including on whether public policies can play a role.

\section{Literature Review}

Our paper builds on two strands of literatures. First, it contributes to the macro literature on corporate saving and the implied rise in the net lending position of corporations. This literature is mostly based on macro evidence from sector-level data, as is the first part of our analysis. Secondly, our paper relates to the very extensive corporate finance literature analyzing the rise in cash holding by US corporations. Papers in this area are mostly empirical and use balance-sheet data at the firm level to identify the drivers of cash accumulation, as we do in the second part of our work. One contribution of our paper is to integrate the corporate view of firms' cash holding with the more macro-level analysis of aggregate corporate sector flow of funds, thus 
providing a consistent top-down understanding of the main trends.

With reference to the first group of macro studies, André et al. (2007) and IMF (2006) were among the first to document the global rise in corporate saving relative to investment in advanced economies, leading to a rise in the net lending position of the non-financial corporate sector. These earlier studies stress the importance of both cyclical and structural factors underlying the rise in corporate saving. In particular, they show how the rise in the corporate net lending position can be explained by a rise in profitability induced by a fall in taxes and interest rates, as well as by a fall in the price of capital, which lowered the cost of investment and therefore contributed to the rise in gross saving. Gruber and Kamin (2016) focus on the role of declining investment in boosting corporate net lending in OECD countries and conclude that this decline was largely cyclical. All these papers generally conclude that corporate net lending positions would reverse substantially as the recovery from the GFC takes hold, a presumption that did not materialize consistently across major advanced economies. Relative to these studies, our paper goes in considerably more detail in assembling different sources of data to analyze the patterns and drivers of corporate net lending as well as the flow of funds across sectors, extending both the country and time coverage, and reconciling the macro and micro level patterns. ${ }^{1}$

While this macro literature mostly aimed at empirically documenting various facts associated with higher corporate saving, a limited number of papers took a more structural approach and developed models to explain the cause of the corporate saving glut and perform counter-factual analysis. For example, Armenter and Hnatkovska (2017) explain the rise in net lending of US corporations by proposing a general equilibrium model where corporate saving arise from the precautionary motive of firms seeking to accumulate financial assets and fund such purchase via equity issuance to avoid being financially constrained in the future, even though debt is fiscally advantageous. More

\footnotetext{
${ }^{1}$ The rise in corporate saving has also been documented for emerging market economies. Bacchetta and Benhima (2015) link the increase in corporate saving in fast-growing EM's with credit constrained firms' need for liquid assets, leading to a complementarity between domestic investment and capital outflows. A similar mechanism is presented in Fan and Kalemli-Özcan (2016), who in addition argue that financial liberalization may not reduce overall corporate saving due to offsetting mechanisms.
} 
recently, Chen et al. (2017) develop a general equilibrium model where the decline in the price of investment goods and real interest rates cause firms to replace labor with capital and increase corporate saving. These saving are then used for share buyback instead of dividend payout due to tax incentives, boosting the average corporate net lending position.

The second branch of literature our paper builds on documents and explains the rise in cash holding at the firm level. This literature is focused on the US and mostly relies on reduced-form evidence from Compustat balance-sheet data. Several factors have been shown to predict cash accumulation by firms. Bates et al. (2009), for instance, finds that firms with higher idiosyncratic risk, higher R\&D expenditures, high Tobin's $q$ recorded the largest increase in cash holdings. The importance of R\&D especially for entrants in recent cohorts has also been emphasized by Begenau and Palazzo (2016), who show that the shift towards intangible capital of the average firm in Compustat is driven by R\&D-intensive firms that go public with progressively less tangible capital relative to assets, while non R\&D-intensive firms keep their tangibility ratios relatively stable over time. Along the same lines, Graham and Leary (2016) attributed the rise in average cash-holding to health and tech firms going public with large cash balances. This result is in line with Booth and Zhou (2013), who showed that the rise in average cash-to-asset ratio is driven by changing firm characteristics of high-tech firms. Closely related to the role of R\&D, another strand of literature studies how increased product market competition gives rise to higher cash holdings by the need to rely on internal funds to finance future investment and gain strategic competitive edge, see e.g. Della Seta (2011), Ma et al. (2014), Morellec et al. (2014) and Lyandres and Palazzo (2016). This contrasts with the idea that firms store cash for lack of investment opportunities, and is rather in line with evidence that the shadow value of cash holding has increased significantly, as in Bates et al. (2016). Finally, wile this last group of paper focuses on understanding how the evolution of certain firms' characteristics has shaped that of cash holdings, other papers in this literature focus instead on the change in institutional factors that affected the business environment. For example, Foley et al. (2007) studied the role of tax-induced 
motive for cash holdings, while Azar et al. (2016) highlights the changes in the costs of holding cash over time. The recent paper by Graham and Leary (2017), studying cash holding over almost a century in the US, also finds that macroeconomic conditions external to the firm, in particular profit opportunities and tax incentives have had an important impact on cash holding among established firms in the US since 2000.

While our paper is motivated by the stylized facts of the first branch of macro literature on net lending, we establish a tighter connection with the conceptual and empirical framework of the second branch of corporate finance literature. Relative to this second group of papers on corporate cash holdings, we are extending the empirical framework to firms in other advanced economies outside the US. Moreover, we link the empirical determinants of cash holdings with the net lending position of firms, consistent with our goal to connect with the macro literature. In doing so, we show that evolving motives for cash holding have also been shaping the rise in corporate saving and net lending, with potentially sizable implications for current accounts across countries.

\section{Aggregate Stylized Facts}

To study corporate excess saving, we compute the net lending position of the corporate sector with respect to the rest of the economy. As is common in the literature, we focus on non-financial corporates only, as financial corporations' balance sheet compositions are strongly influenced by regulatory standards.

Consider the following definition of net lending:

$$
\text { NetLend }=\text { GrossSaving }- \text { CapitalExpenditure, }
$$

where GrossSaving stands for the amount of firms' aggregate net income, gross of depreciation, that are not distributed to shareholders, while CapitalExpenditure refers to firms' aggregate investment in physical capital.

In Figure 1, we aggregate the net lending position of the non-financial corporate

7

CInternational Monetary Fund. Not for Redistribution 
sector and its two components, gross saving and capital expenditure, to the level of the G7 group as a whole. ${ }^{2}$ Up until the early 1990's, corporations had persistently been net borrowers of funds as one would expect, but this behavior has reversed since then. The striking pattern shown in Figure 1 is that corporations across the G7 have started consolidating their net lending position, both through larger gross saving and lower investment rates, since the early 1990's. Around the early 2000's, non-financial corporations in the G-7 have swung from being net borrowers of funds from the rest of the economy to net lenders. ${ }^{3}$ This means that the rise in net lending is a relatively long-standing phenomenon, pre-dating the recent Global Financial Crisis.

In the remainder of this section, we show that the aggregated stylized fact of rising corporate net lending also holds within the vast majority of individual countries in our sample. First, we explore firms' net lending dynamics by country and show how they contribute to each country's overall saving-investment or current account balance. Secondly, we investigate the sources of corporate excess saving. That is, we examine whether the increase in excess saving is mainly due to firms' rising profitability, falling share of distributed income in percent total profits, decreasing capital investment, or a combination of all of these facts. Finally, we study the evolution of the uses of excess saving, documenting shifts in firms' asset composition that accompany their increasing net lending position.

\subsection{Corporate net lending and current account positions}

Consider the following definition of a country's current account balance:

$$
C A=\text { Saving }- \text { Investment }=\text { NetLendingoftheTotalEconomy }=\sum_{s} \text { NetLend }{ }_{s}
$$

\footnotetext{
${ }^{2}$ The G-7 group represents the largest industrialized countries worldwide and is computed as the GDP-weighted average of the US, UK, Canada, Japan, Germany, Italy, and France.

${ }^{3}$ Our dataset starts from 1995, because this is as far back in time as we can go with European data, provided by Eurostat and compiled according to the European System of National and Regional Accounts (ESA) 2010. Accordingly, ESA 2010 represents the newest internationally comparable EU accounting framework consistent with the worldwide guidelines on national accounting set out in the System of National Accounts 2008 (SNA 2008).
} 
where $s \in\{H H \& N P I S H, F C, N F C, G G\}$ indexes each of the sectors that sum up to the total domestic economy, that is, households and non-profit institutions serving households (henceforth $H H \& N P I S H$ ), corporations - further separated into financial $(F C)$ and non-financial $(N F C)$ corporations and the general government $(G G)$.

Figure 2 plots the net lending position of each sector within each country of our sample and shows how the sectoral net lending position contributes to the net lending of the domestic economy. Three interesting facts emerge from Figure 2. First, while countries in the sample show very heterogeneous dynamics of their current account position $^{4}$, the corporate sector became a net lender everywhere, except for France and Korea, with different timing across countries starting from the early 2000s. In Korea, corporations are still net borrowers, but they decreased their net borrowing position dramatically in the last 15 years. Hence, the increase in corporate excess saving is a robust feature across major economies, regardless of their current account position.

The contribution of the corporate sector to overall current account balances is even more prominent in periods of large changes to the external balance. Whenever there is a large upward spike in a country's current account balance, and regardless of the current account level, most of the increase is driven by the corporate sector. This is the case for example in Germany in the early 2000, Korea after the Asian crisis, the US in 2009, and Italy in 2012. Second, in countries where firms became net lenders, $H H \& N P I S H$ have not offset this shift by increasing their net borrowing position as would be the case if households would "pierce the corporate veil" as predicted by theory (see Poterba et al. (1987)). Rather, with household net lending position unchanged, higher corporate net lending tends to translate into a higher a private net lending position overall. Finally, while the private sector is significantly contributing to the overall current account balance, the government also plays an important role in determining the current balance positions. In the UK and the US, for instance, government's borrowing from the rest of the economy more than compensated the

\footnotetext{
${ }^{4}$ On the one hand, countries like Germany, Japan, Korea and the Netherlands have been recording large and persistent current account positions. On the other hand, the UK and the USA have been constantly running current accounts deficits. Evidence is mixed for Canada, which turned into a deficit country only since 2013, France, in deficit since 2007, and Italy, which is currently running a current account surplus after being in deficit since the 2000 .
} 
private sector's saving surplus, so that these countries have been running a persistent current account deficit. In Germany, Japan, Korea and the Netherlands, on the other hand, the saving behavior of the private sector has not been compensated by the government, so that these countries show a persistent current account surplus position. Overall, given the role that corporate net lending has in driving overall current account positions across countries, it is increasingly important to understand the drivers of corporate saving and net lending as new insights may shed light on drivers and causes for global imbalances.

\subsection{The sources of corporate net lending}

In this section we focus on sources behind the rise in firms' net lending position, restricting our analysis to the non-financial corporations as is common in the literature. $^{5}$

We first analyze the dynamics of the components of net lending as defined in equation (1). Consider again Figure 3, which plots net lending for the non-financial corporate sector, decomposing it into the underlying series for gross saving and capital expenditure. In most countries, we see a positive trend in gross saving. The rise is particular significant and persistent in Germany, Japan, Korea and in the Netherlands. On the other hand, capital expenditure fell everywhere or showed no trend. The fall in capital expenditure is particularly stark in Germany and UK. We can summarize our findings as follows: (i) while saving more and more of their profits over time, firms have not been using these saving to finance greater capital expenditures, (ii) in all countries, the shift of corporations to net lenders has been driven by a combination of both a rise in gross saving and a fall in capital expenditure, (iii) Germany, Japan, Korea and the Netherlands, which are the countries with the greatest and most persistent current account surpluses, show the most significant rise in firms' gross saving.

Secondly, we delve deeper into the dynamics of gross saving and check the evol-

\footnotetext{
${ }^{5}$ Indeed the evolution of net lending for the corporate sector as a whole is largely determined by that of non-financial corporations
} 
ution of its components, focusing in particular on countries which experienced the strongest increase: Germany, Japan, Korea and the Netherlands. Accordingly, consider the following definition

$$
\begin{aligned}
\text { GrossSaving } & =\text { GrossProfit-Dividends paid } \\
& =\text { NetIncome }+ \text { Depreciation }- \text { Dividends paid } \\
\text { NetIncome } & =\text { GOS }+P I+\text { NetRE } E_{F D I}+\text { NetTransfers } \\
& - \text { Net Interest paid }- \text { IncTaxes, }
\end{aligned}
$$

where GrossProfit stands for firms' profit (net income) gross of the depreciation of physical capital. The first decomposition allows us to determine whether the rise in firms' saving is driven by a rise in firms' incomes or by a fall in distributed dividends. Moreover, we can decompose the change in net income into gross operating surplus (GOS), net property incomes (PI) and transfers received, less net interest and corporate income taxes paid. Accordingly, consider Figure 4, which decomposes for each country the total change in gross saving rates over the whole sample period into source components according to national accounts definition. In all countries where gross saving have increased over the last 20 years, they has been doing so on the back of increased profits, both from domestic operations (GOS), and/or from (real and financial) investments abroad (reflected in FDI related retained earnings and net PI), as well as by lower interest payments. At the same time, dividend payouts, while also increasing, have done so by much less than corporate income, leading to saving rates that stand up to 3-7 percent of GDP higher now compared to 20 years ago. Payment of corporate taxes, instead of rising proportionately with profits, have instead declined in almost all advanced economies shown, and in countries where tax payments have increased, they did so by much less than corporate profits (Germany, Korea).

For countries where the corporate gross saving rate increased, Japan, Korea, Germany and the Netherlands exhibited the most persistent positive trend in firms' profitability, as shown by the breakdown year by year in Figure 16 in the Appendix. 
Among these countries, distributed income as a share of profits fell particularly postGFC in Germany. Profitability has been rising in the US as well, with the exception for the years of the global financial crisis. In summary, among countries which exhibit the strongest rise in firms' saving and the most persistent current account surpluses, higher profitability (broadly defined, including income from financial investment and FDI) has been the most important source for this trend, reflecting forces that give rise to increased ability of firms to extract operating surpluses, while the decrease in distributed income played a role, if any at all, only during the GFC (US, Japan, Korea) or afterward (as for Germany). By contrast, the impact of taxes and interest payments is less uniform. Notably, the corporate sector in Japan and Korea stand out during the mid-1990's to early 2000's, when higher corporate net income was mostly driven by declining interest payments, reflecting large-scale deleveraging in the aftermath of banking crises.

Zooming in on the positive trend in GOS, in turn, we can further shed light on whether higher corporate GOS has been a result of stronger productivity growth (relative to other sectors of the economy), or lower labor income shares and production taxes, or both. That is, we decompose:

$$
G O S=G V A-C o m p E m p-\operatorname{ProdTax}
$$

Figure 5 summarizes the relationship between long-run changes in GOS and corporate gross value-added (GVA), both expressed in percent of GDP, as well as labor incomes shares respectively. ${ }^{6}$ Clearly, both a higher share of corporate GVA as well a lower share of GVA that is paid to labor have been accompanying higher shares of GOS in countries where it increased the most. While the former shift could be driven by higher productivity growth or structural transformation, the latter trend, widely documented (see e.g. Dao et al. (2017)) can be the result of technology, globalization, or changes in workers' bargaining power.

To summarize, the rise in corporate net lending has been driven by a combination

\footnotetext{
${ }^{6}$ That is, we show each country's position along the schedule $\Delta \frac{G O S}{Y}=\beta_{1} \Delta \frac{G V A}{Y}-\beta_{2} \Delta \frac{w L}{G V A}-$ $\beta_{3} \Delta \frac{\operatorname{ProdTax}}{G V A}, \beta_{1}, \beta_{2}, \beta_{3}>0$.
} 
of rising gross saving and falling capital expenditure. Among countries with the most significant increase in gross saving and current account surpluses (Japan, Korea, Netherlands, Germany), this trend was mostly driven by a rise in gross profitability, and, only after the global financial crisis, to a fall in dividends distributed as a share of total profits. Across much of the sample, rising operating surpluses (including retained earnings and property income from foreign operations) have been further supported by lower interest payments and stagnating tax payments (i.e. declining effective tax rates).

\subsection{The uses of corporate net lending}

Having documented the pervasive trend in rising corporate net lending and the dominant source for this trend, we now turn to the question of how firms have been using these excess saving. That is, we document how firms have been allocating their excess saving across different types of assets on their balance sheets. This exercise will shed light on the reasons behind firms' accumulation of internal resources, depending on the dominant type of financial asset they invest in. To start off, consider the following equation describing the use of firms' gross saving:

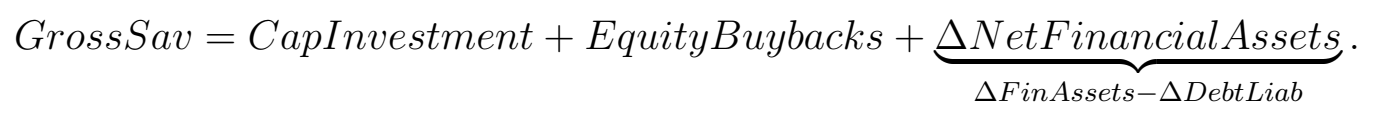

This equation shows that corporations must choose how to allocate the fraction of profits that they do not distribute to shareholders among investment in physical capital, paying shareholders through equity buybacks and adjusting the composition of their balance sheets.

At the aggregate level, it is not possible to measure actual value of equity buyback of the total corporate sector as we only observe the net change of equity liability of all firms, which subsumes new equity issuances of existing firms and new entrants. However, we know from other studies that, although equity buybacks do represent a common use of corporate excess saving, they cannot account for the bulk of the rise in corporate net lending in OECD countries (e.g. Chen et al. (2017)). In other 
words, much of the excess saving must have gone toward changing the composition of balance sheets and the net financial asset position (the last term on the right hand side of equation 4). We also confirm that this is the case by plotting the time series of aggregate corporate net lending flows against the evolution of corporate net financial asset positions in Figure 6. To build our measure of the net financial asset position (NFA hereafter), we follow Armenter and Hnatkovska (2017) and define it as the difference between the sectoral financial assets minus debt. When constructing debt, we subtract equity from the total value of liabilities. Details on how we construct each measure from the sectoral balance sheet data of each country are provided in the Appendix. By and large, increasing net lending is strongly associated with improving net asset position and vice versa within each country. A simple panel regression with country fixed effects shows that a 1 percent of GDP higher net lending rate within countries is associated with a 1.6 percent higher net financial asset position of the corporate sector on average, with the coefficient estimate being highly statistically significant. Accordingly, in the following, we abstract from equity buyback and focus on the balance-sheet impact or use of firms' net lending through the following approximation: ${ }^{7}$

$$
\text { NetLend }=\text { GrossSav }- \text { CapInvestment } \approx \Delta \text { NetFinAssets } .
$$

In Figure 7, we decompose the evolution of the aggregate NFA position into the underlying series for financial assets and debt. Clearly, firms have not used their excess saving to pay down debt in a systematic way across countries. Indeed, with the exception of Italy and Japan, the level of debt has increased in all countries. Instead, the data suggest that firms have been increasing both overall financial assets and debt, but they have been using their excess saving to increase their overall asset position beyond the increase in debt.

We can also more systematically account for the different uses of net lending

\footnotetext{
${ }^{7}$ We do not rule out that some of the balance sheet composition change is driven by the motive of share buybacks, e.g. cash position may be higher in times when the firms decides to buy back shares using its internal funds, possibly with some lag, and revisit the buyback motive for net lending and cash holding at the firm level in section 4.
} 
flows by jointly correlating them with all major uses recorded in aggregate financial accounts. That is, we regress the share of non-financial corporate net lending over GDP on the main balance-sheet variables from the assets side. Overall, corporate saving in excess of investment (i.e. corporate net lending) can be used to either buy back shares, pay down debt, or acquire financial assets (which in turn can be broken down into equity, loan/account receivables, debt or cash assets). While all uses have been relevant in different countries and years, simple regressions using flow of funds and sectoral financial accounts data across countries in our sample show that the accumulation of cash has been the most salient use of corporate net lending. As shown in Table 1, changes in the cash ratio (that is, cash in percent of total financial assets) are strongly associated with higher corporate net lending positions, both in the pooled and within-country regressions, suggesting that cash accumulation has been a major use of corporate net lending.

To illustrate the tight link between corporate excess saving/net lending and cash holding, we plot the two series against each other for each country in the sample. As it turns out, the rise in corporate net lending position has been mirrored by that in the stock of cash and liquid assets on firms' balance sheets. We show this fact in Figure 9, which plots the share of corporate net lending over GDP with the share of cash and liquid assets over total financial assets. ${ }^{8}$ The correlation between net lending and cash ratios is very tight within each country, implying that, at least in the short-run, firms have been accumulating excess saving to boost cash holdings. Among countries in the sample, the correlation between net lending and cash holding has been particularly strong in Germany and the Netherlands.

While the evidence thus far does not necessarily imply a causal relationship between holdings of liquid assets and corporate net lending, it still suggests that, whatever the motives for the rise in cash holdings, they likely play a role in driving a rise in net lending as well. This leads to the second part of our analysis, where we

\footnotetext{
${ }^{8}$ We construct this graph with sectoral balance-sheet data for non-financial corporations, as recorded in the Financial Accounts of each country. Our measure of cash and liquid assets includes short-term securities, mutual fund shares and repo; see the Appendix for details on how this variable is constructed using sectoral balance-sheet. Note that for Korea, we lack consistent aggregate balance-sheet data spanning across the entire sample.
} 
move to micro data to identify the characteristics of firms that account for the rise in corporate cash holdings and net lending flows, and provide a more granular view of the aggregate trends documented so far.

\section{Firm-level analysis}

In the following, we use firm-level data to further shed light on the determinants of cash holding, as such factors are likely to be driving the corporate saving dynamics established in the previous analysis. We use a comprehensive dataset covering consolidated financial statements of publicly listed companies in major advanced economies from Thomson Reuters Worldscope. Although public firms only make up a subset of firms of each country, they encompass the largest and most profitable firms and hence are likely to drive the aggregate saving dynamics of the whole corporate sector. In fact, unlike aggregate employment and wage bill, which are to a large extent determined by small and medium-sized enterprises, aggregate profits and investment are much more concentrated among large firms, which renders our dataset well-suited to study the behavior of corporate saving. Table 2 summarizes the coverage in our firm-level data for the G7+2 countries in the sample between 1999 and 2014 by showing the ratio of total gross profits, gross saving and investment, aggregated over all non-financial firms in our dataset relative to the corresponding measure in national accounts. Although capturing only a subset of firms in the economy and despite differences in definition of profits and saving from the system of national accounts and corresponding measurement in corporate financial statements, our micro data captures on average a large share of aggregate profits, saving and investment (more than 30 and up to 75 percent of national gross saving) ${ }^{9}$

More importantly, the excess saving rate - our main object of interest - aggregated from our firm-level data tracks well the actual aggregate corporate net lending rate from national accounts data. We check this by plotting in Figure 10 the aggregate

\footnotetext{
${ }^{9}$ Differences in definition concern the treatment of income from subsidiaries abroad, employer contributions to pension funds, exercise of stock options, see André et al. (2007).
} 
NFC net lending rate (in percent of GDP) from flow of funds/national accounts data used above against the median net lending rate (in percent of sales) of all companies in Worldscope aggregated over all firms in each country and year. As expected, with the exception of Canada, the two series show very strong correlation. The correlation coefficient ranges from 0.3 (in France) to 0.9 (in Germany). Studying the saving and cash management behavior of publicly listed firms therefore potentially offers both the granularity to understand the microeconomic determinants of corporate saving, as well as the macro-relevance of such factors in terms of shaping the aggregate saving investment balances.

\subsection{Stylized facts}

We start by documenting the relationship between cash holding and firm size. In Figure 11, we plot the median holding of cash and short-term investment over total assets by quantiles of firm size (in terms of total assets, though robust to total sales) averaged over the first and second decade of the sample. The cash-size schedule is mostly downward sloping within each period, consistent with the well-documented fact that smaller firms hold a higher share of their assets as cash. Over time however, cash ratios have increased for all size classes in most countries, except in Japan where cash holdings of the largest firms has somewhat decreased (from very high levels) and in Italy, where smaller and medium-size firms have shown some reduction in cash stocks as well.

We repeat the same exercise with firms' net lending positions, as shown in Figure 12. In particular, we plot the median share of net lending over total sales by quantiles of firm size. Consistent with the trend at the macro level, the net lending position of corporations in our data has also increased over time, and generally did so over the entire spectrum of firm size, similar to the trend in cash holdings. Finally, in Figure 8 we document that the rise in cash accumulation over the period $1995-2014$ is also common across industries, and is particularly pronounced for IT-intensive industries, again pointing to a broad-based trend.

Changes in average and median cash ratios in the aggregate or individual indus- 
tries as documented so far can be driven either by changing cash holding among incumbent firms firms, or by changing composition of firms. For example, Begenau and Palazzo (2016) argue that the firms entering the stock market in the 1980's and 1990's in the US typically held more cash at entry, compared to incumbent firms. If this trend had continued and operated also in other countries, the broad based increase in cash ratios could be driven primarily by shifting composition of public firms across advanced economies, most notably by the increasing importance of high-tech, R\&D-intensive firms as was the case with NASDAQ firms in the US in the last few decades (Begenau and Palazzo (2016); Graham and Leary (2016)). To separate the compositional change driven by entry/exit from the change among incumbent firms, we conduct a decomposition of the average cash ratio evolution in each country along the extensive (that is, driven by entry and exit) and the intensive (that is, driven by evolution of the average incumbent firm) margins as follows:

$$
\begin{aligned}
\Delta \frac{C H_{t}}{A_{t}} & =\underbrace{\left(\frac{A_{t}^{I}}{A_{t}^{I}+A_{t}^{\text {entr }}} \frac{C H_{t}^{I}}{A_{t}^{I}}-\frac{A_{t-1}^{I}}{A_{t-1}^{I}+A_{t-1}^{\text {exit }}} \frac{C H_{t-1}^{I}}{A_{t-1}^{I}}\right)}_{\text {intensive margin }} \\
& +\underbrace{\left(\frac{A_{t}^{\text {entr }}}{A_{t}^{I}+A_{t}^{\text {entr }}} \frac{C H_{t}^{\text {entr }}}{A_{t}^{\text {entr }}}-\frac{A_{t-1}^{I}}{A_{t-1}^{I}+A_{t-1}^{\text {exit }}} \frac{C H_{t-1}^{\text {exit }}}{A_{t-1}^{\text {exit }}}\right)}_{\text {extensive margin }},
\end{aligned}
$$

with the superscript $I$ designating the corresponding variable (cash stock $C H$ and total assets $A$ ) of incumbent firms. Figure 13 presents the decomposition for each of the G-7 countries where coverage in the Worldscope dataset has sufficient mass of surviving firms for the exercise to deliver reasonably stable results. A common feature among most countries is that the increase in average cash ratios in the last decade has been primarily driven by rising cash ratios within incumbent firms. Interestingly, this represents a notable shift for the US, where for the years prior to the 2000's, our decomposition confirms the finding in the literature that the rise in average cash holding had been driven by high-tech firms intensive in R\&D entering the stock market with higher cash reserves. However, since the early 2000's, this trend has flattened 
and even started reversing around the mid 2000 (when entry and exit of firms has started to contribute negatively to average cash holding), while the continued rise in cash stocks has been driven by higher cash holdings of incumbent public firms (also observed in Graham and Leary (2017)). This trend is confirmed for the other G-7 countries outside the US: cash holding as a share of overall assets has been rising within incumbent firms in Germany, France, Canada and the UK, while it also started to pick up in Japan and Italy around the global financial crisis, just when aggregate corporate net lending in these two countries also increased substantially (see Figure 2), reversing the current account deficit into a surplus in the case of Italy. In light of the prominent role of the intensive margin for the increase in corporate cash and net lending in the last decade, which further complements the uniform pattern of higher net lending and cash holding across the distribution of firm size (Figure 11), we focus on drivers of cash holding among and within incumbent firms in the following.

\subsection{Drivers of corporate cash holding}

The finance literature has established a widely-used empirical framework to estimate drivers of corporate cash holding, mainly focused on the US, underpinned by various theoretical motives for cash holding, notably the precautionary, transactional, and agency motives (see e.g. Bates et al. (2009) the US and Pinkowitz et al. (2015) for a cross-country study). We follow the literature in specifying a simple regression model that combines firm-level and aggregate level data across the sample of industrial countries. In doing so, we can exploit the heterogeneity in cash holding across firms, industries, and countries, as well as the differential timing of the rise in cash holding and net lending across these dimensions. In light of the observation that the rise in cash holding is driven by evolutions within incumbent firms, we limit the regression to firms which are observed for at least 18 years (out of the 20-year sample).

The first set of results obtained by pooling observations across all incumbent firms within each country are reported in Table 3 and broadly confirm previous findings in the literature. First, consistent with the transaction motive of cash holding, cash ratios decrease with firm size (as measured by the log of total book assets) as larger 
firms benefit from economies of scale in their operational transactions, see (Miller and Orr, 1966). The transaction motive would also predict that firms with more volatile cash flows hold more cash reserves to avoid having to sell other assets and incur transaction costs, consistent with our positive estimate on industry-level and aggregate volatility. We follow Bates et al. (2009) in computing the industry cash-flow volatility as follows: for each firm-year the standard deviation of a firm's cash-flow to assets is computed for the past ten years. We limit the computation to firms with at least three running 10-year observations available over the sample period. Finally, the firm-level observations are averaged over the two digit SIC industries. Aggregate uncertainty is measured by the policy uncertainty (EPU) index from Baker et al. (2016).

Most of the recent theoretical and empirical work have centered around the precautionary motive of cash holding, which predicts that firms facing more uncertainty from various sources should hold more cash for self-insurance. This precautionary motive applies particularly to firms with stronger growth opportunities, as the cost of foregoing an investment opportunity due to a lack of funds is higher for them; and it should also be stronger for firms with investment projects that are subject to more severe informational asymmetries, for which internal financing is more crucial. Consistent with these priors, we estimate a positive, statistically significant effect of Tobin's Q (market-to-book value), as well as $R \& D$ intensity ( $R \& D$ spending in percent of sales) and age (IPO year) on the cash ratios across firms. The positive effects of industry-level cash flow volatility and aggregate policy uncertainty (measured by the EPU index) are also consistent with the precautionary motive, in addition to the transaction motive. Informational asymmetry may also explain the negative correlation of leverage ratio with cash ratio as firms prefer to finance projects internally before turning to issuing debt (and equity) as per the pecking order theory, as well as the positive effect of profit on cash ratios - a consequence of sticky dividend policy firms choose to avoid negative signaling effects.

Confirming results in previous literature, we also find that firms which pay dividends have lower a cash ratio, consistent with the agency motive. This can be 
driven by differences in shareholder protection rights, which in turn influence the dividend payout ratio, for given firm performance (Dittmar et al., 2003). Another important motive for cash holding that has gained much recent attention in the US is the tax motive, according to which firms residing in high corporate tax countries but having income abroad tend to keep higher cash ratios to avoid repatriating and paying taxes in the home country under a worldwide corporate income tax system. ${ }^{10}$ Indeed, we find that the share of foreign sales (which may earned through exports or subsidiary income) has a strong positive effect on the consolidated firm's cash holding. The mechanism for foreign sales on corporate cash is, however, unclear: it could be that firms with more foreign sales are exporters and/or multi-nationals, who are need more internal financing to finance cross-border production value chains (Shin et al. 2014), or it could be because these global firms are precisely those who have the capacity to engage in profit shifting and hence tend to hoard cash with foreign affiliates to avoid costly repatriation (Foley et al. 2007). Finally, as working capital such as inventory, intermediate (especially commodity) inputs can serve as substitute for cash due to their relative liquid nature, it has been shown that as firms switch to lower inventory stocks following improvements in logistics and storage technology, their freed-up resources also contributed to raising the cash ratios in the US (Gao et al., 2013). We confirm this negative correlation in our broader sample as well. Overall, controlling for the aforementioned drivers lowers the estimated coefficient on the linear time trend by about half (columns 3 versus 4). As the flow of net lending (excess saving) is an important, though not the only, source for cash accumulation, we replace the dependent variable with the net lending ratio (in percent of sales) while keeping the same set of explanatory variables in column 5. Controlling for contemporaneous profits, higher foreign sales exposure and $R \& D$ intensity is also associated with higher excess saving, indicating that at least part of their positive effect on cash is realized through adjustments in corporate saving/retained earnings.

Results from Table 3 described so far are obtained from pooled regressions and

\footnotetext{
${ }^{10}$ For example, the WSJ on April 25th, 2016 reports that "S\&P 500 companies including Pfizer, Apple Inc. and Microsoft Corp. indefinitely put away a record $\$ 2.3$ trillion of cumulative foreign earnings by the end of 2015.".
} 
represent correlations both across firms as well as within firms over time. Although we know from Figure 13 that average cash holdings have been primarily driven by changes among incumbent firms over time, regression so far could point to either changes key characteristics (such as higher profits, higher $R \& D$ etc) driving cash holding within the average firm, or reallocation of market shares toward firms with higher cash holding and similar characteristics over time. We explore in the following determinants within firms over time. Results using within-firm variation are reported in Table 4. The sign, statistical significance and magnitude of most coefficient estimates are the same as in the pooled regressions, suggesting that at least part of the correlation identified in the pooled regression is driven by correlation within firms. In particular, the effect of higher profits on cash ratio within firms is considerably higher than in the pooled estimation (0.12 to 0.2 compared to $0.05-0.06)$, indicating that dividend stickiness within firms may indeed play the main role in driving this correlation. In contrast, the estimated positive effect of foreign sales exposure seems to be driven by the cross-sectional correlation, with the within-firm correlation being not statistically significant, lending prima facie more support to the tax motive (whose strength arguably varies most across than within firms) than the exporter/GVC channel. We also confirm robustness of main results to using the natural logarithm of the cash ratio as dependent variable (often preferred for ratios to limit non-classical measurement errors) in column (2), as well as estimating the within-firm regression using first differences in column (4). One notable difference is the much weaker effect of cash-flow volatility in the first difference estimation, suggesting that the positive effect of industry-specific volatility on firm-level cash holding appears to only operate over time and not be reflected in contemporaneous increase in cash holding. Finally, we estimated both the within-firm and first-differenced regressions using the non-US sample as well (columns 3 and 5) and find that most coefficients estimates are not significantly different across subsamples with and without US firms, indicating broad-based validity of the determinants.

Regression results reported so far treated missing observations for $R \& D$ spending as zero, following the convention in the literature. To check if our results are driven 
by such assumptions, we also rerun the main regressions using only the sub-sample of firm-year observations with non-missing $R \& D$ spending, as reported in Table 5 . Although the number of observations is reduced by roughly a third compared to the full sample, the results are remarkably stable. One notable exception is the estimated positive effect of $R \& D$, which is now quantitatively smaller relative to both the pooled and within regression using the full sample (still strongly statistically significant), as it now only captures the effect of variation in intensive margin of innovation spending on cash holding, and not the extensive margin effect of becoming an innovator on firms' cash holding.

It has been often argued that the allocation of intangible capital, particularly intellectual property $(I P)$, across affiliates of a multi-national group can be exploited to shift profit to low-tax jurisdictions, as surveyed in Johansson et al. (2017). The consistent positive effect of $R \& D$ spending that we find could therefore be driven by firms that report high $R \& D$ spending allocating much of the resulting $I P$ assets with affiliates residing in jurisdictions with low tax rates or preferential tax treatment of IPgenerated income, and hoard such income (derived from patent, royalties) in cash to defer repatriation. If this is the case, the effect of $R \& D$ and foreign sales exposure that we are estimating would then mainly capture the tax motive. To disentangle them in the following, we control directly for the effective tax rate (ETR) paid by a given firm, computed as $E T R=$ Sum of all taxes (domestic and foreign) paid/Pre-tax book income as reported in the consolidated financial accounts. This measure of ETR has been commonly used in the literature - see e.g. Markle and Shackelford (2012) - to measure the tax burden of a firm at the consolidated level of the multinational firm. The identifying assumption is that, once key firm characteristics (such as size, industry, cash flow) are controlled for, variation in ETR particularly between multinational and domestic firms, but also within a multinational firm over time reflects the degree of profit shifting and tax-minimization strategies, particularly as conducted by large, publicly-listed firms as those in our dataset. ${ }^{11}$ Results for pooled and within-firm

\footnotetext{
${ }^{11}$ This is admittedly only a crude measure of the ex-post outcome of tax strategies: they include current and deferred taxes that are reported in financial accounts, and changes in the ETR can be also driven by changes in statutory tax rates over time and/or in the definition of the tax base. That
} 
regressions controlling for the ETR and using the non-missing $R \& D$ sample are summarized in Table 6.

The first result to note is that, conditional on other relevant observables, firms with lower effective tax rates indeed have higher cash ratios (column 1 of Table $6)$, consistent with the tax motive of cash hoarding. That said, this finding only indirectly supports the tax motive of cash holding, as the dependent variable is the cash ratio at the consolidated basis of the group (instead of unconsolidated foreign affiliates' cash holding), and the estimated correlation could also be due to lower taxes mechanically translating to higher cash ratios even among domestic firms if the tax saving is considered temporary and hence not distributed as dividend. More importantly, the positive effect of $R \& D$ spending as well as foreign sales exposure remain unchanged (compared to column 1 of Table 3), suggesting that such correlation is not primarily driven by tax minimization strategies. Not surprisingly, the positive effect of lower ETR on cash holding is weaker within firms (column 2), as most of the variation will come from different firms having differential capacity of engaging in strategic tax planning, rather than a given firm being able to vary such capacity over time. Conditional on the ETR, when a given firm increases its $R \& D$ spending, we still see its cash holding increase, while again increased foreign sale exposure is not systematically associated with higher cash. As before, we confirm the results' robustness when using the log cash ratio and limiting the sample to non-missing $R \& D$ sample only, with the coefficient estimate for $R \& D$ spending being very similar (if not somewhat higher) than in specifications without the ETR.

To further rule out that our results are driven by the tax motive, we limit the sample to firms with non-missing zero foreign assets (that is, firms without wholly owned foreign subsidiaries) in column 5 and re-run the baseline panel regression. For this sub-sample of domestic firms, tax-related profit shifting across worldwide affiliates are least likely to drive the overall cash holding. Despite the substantial reduction in observations, coefficient estimates remain very similar to those obtained

said, at least in the US, about two-third of the decline in the ETR over the sample period can be attributed to increased tax avoidance, see Zucman (2014). 
in the baseline, while the coefficient estimate on the ETR variable is only weakly statistically significant as expected. In contrast, the positive effect of $R \& D$ is almost identical to the baseline estimate while the effect of foreign sales, here most likely driven by exports, is strengthened. While the exercise conducted so far does not serve to deny the tax motive for corporate cash holding among multinational firms, it provides consistent evidence that other forces were at work in shaping the demand for corporate cash at the same time, and that such forces were operating similarly across all major advanced economies (similar to findings in Pinkowitz et al. (2015)).

\subsection{Drivers of corporate net lending}

We have so far identified key drivers of corporate cash holding across major advanced economies, but have yet to confirm that these drivers were also influencing corporate excess saving (net lending) flows, which tend to co-move strongly with cash holding (as shown in Figure 9), in the same way. This need not be the case since firms

may increase cash holding through various channel other than retaining earnings, including by issuing equity and/or debt. In the next step, we test if the same factors can also explain the behavior of net lending rates by replacing the dependent variable in all regressions with the firm-level measure of net lending (or excess saving/change in retained earnings), defined as follows to closely match the concept of corporate saving investment balance in aggregate flow of funds:

Net Lending $=$ Net Income + Depreciation - Dividend paid-Capital Expenditure

Results of the net lending regressions are reported in Table 7. Column 1 shows that in the pooled regression, larger, more profitable firms, and those with foreign exposure, larger amount of working capital, and higher market valuation have higher net lending (or excess saving) rates. Such firms also tend to be less leveraged and pay less dividends, partly as a way to boost retained earnings/net lending. Importantly, firms with higher $R \& D$ intensity have higher net lending positions, consistent with the presumption that some of the higher cash associated with innovation intensity 
is achieved with higher excess saving. However, the results in column 2 reveal that such long-run adjustment of corporate saving to innovation spending does not occur immediately, as the estimate of the contemporaneous $R \& D$ coefficient becomes insignificant in the within-firm regression. Instead, firms may boost saving over time to build up cash holding in anticipation of higher innovation spending in the future. Indeed, this is what we find when controlling for the one and two-year forward looking $R \& D$ spending intensity in the within-firm regression (columns 3-6): Conditional on current profits and balance sheet conditions, firms that expect to have higher $R \& D$ spending in 1-2 years time start increasing their retained earnings ahead of time. This result is more precisely estimated when we restrict the sample to firms with non-missing $R \& D$ spending, possibly due to smaller measurement error in their innovation spending. Finally, we expect firms to be more able to retain earnings for cash accumulation if they have higher earnings to begin with, as firms with low profitability naturally will have less internal capacity for cash accumulation. In columns 5-6 of Table 7, we restrict the net lending regression to firms with profit rates (measured by net margin in percent of revenues) above the median and above the 75th quintile, respectively. Consistent with our prior, more profitable firms retain more of their earnings 1-2 year prior to ramping up their $R \& D$ spending: For a firm in the upper quartile of the profitability distribution, an anticipated increase of 10 percent in $R \& D$ spending (as a share of sales) is associated with cumulatively 1 percent higher excess saving (also relative to sales) in the preceding 2 years as compared to only 0.4 percent for the average firm.

Stock repurchases are a common practice for firms to transfer accrued returns to shareholders, or to offset dilution incurred by employee stock option issuances, or in general to manipulate earning per share to boost investor confidence, see Dittmar (2000). It has also been documented that incidences of stock repurchases have increased in recent years, particularly among high-tech firms. As such repurchases are commonly financed by cash, the rise in cash, accumulated in part by running positive net lending positions, may well be at least in part driven by the desire to repurchase shares within a planning period of 1-2 years, and the correlation between $R \& D$ in- 
tensity and cash ratio could spuriously be capturing this motive. An advantage of firm-level data, as opposed to aggregate flow of funds data, is that it allows us to construct good proxies for stock repurchases based on the number of shares outstanding in each year. Table 8 shows key regressions for cash holding and net lending as before, but in addition controls for a proxy for share repurchases. The variable is constructed as the year-on-year change in the number of shares outstanding (in percent) in years that see a decrease in public shares, and zero otherwise. The regression results for cash and net lending while controlling for buyback reveal interesting patterns: firms tend to hoard cash 1-2 years ahead of a buyback event and retain more earnings (i.e. increase net lending) in the year of the buyback. For a common volume of buyback (corresponding to 2 to 3 percent of shares outstanding), the estimates predict a net lending rate increase of roughly one tenth of the average rate. While these results support the prior that retained earnings have been used to finance buybacks, they do not overturn any of the previous results, and in particular, the coefficients on $R \& D$ intensity is largely unchanged.

Is the empirical model able to account for the broad-based trend in rising corporate net lending observed over the past 15 years? Figure 14 gives an answer to this question by comparing time trends extracted from a regression of firm-level net lending on country, firm and year fixed effects only, compared to those extracted from the full model (from Table 7) which controls for the determinants of cash holding. First of all, the (unconditional) rising trend in corporate net lending is strongly present in firmlevel data (left panel in Figure 14), which shows that the average public firm in major advanced economies now has a 3 percent higher excess saving rate compared to the mid 1990's. This is true both for the within-firm trend as well as the cross-sectional average. Once we control for the explanatory variables in the cash regression, however, the remaining time trend is flat, suggesting the factors driving higher demand for cash do explain to a large extent the surge in corporate net lending, consistent with the unconditional correlation between cash and net lending from aggregate data as previously presented in Figure 9 and Table 1. More profitable firms saw their retained earnings increase more steeply (right panel in Figure 14), and up until the mid 2000's, 
rising spending on $R \& D$ accounted for much of the rising propensity for corporate excess saving of the most profitable firms (see difference in residual time trend between the model with and without $R \& D)$.

Of course, as the results in Table 7 show, apart from $R \& D$ spending, other firm characteristics have also significantly contributed toward raising corporate net lending. In fact, since the mid 2000, it is the combination of these other trends driving profitability and asset expansion that appear to contribute the most to higher corporate saving and net lending (residual time trends flat and statistically identical between both models with and without $R \& D$ in right panel of Figure 14). One way to illustrate the estimated magnitude of each empirical determinant is to decompose the average long-run change in corporate excess saving/net lending rate into predicted contributions from the different covariates. As most of the change comes from the within-firm dynamics, we can use the regression result in column 5 of Table 8 and apply the estimated coefficients to the long-run change in each explanatory variable over the sample period (1995-2012) to decompose the overall long-run change in the dependent variable (net lending rate) into estimated contributions from each explanatory variable (and an unexplained residual). This decomposition in presented in Figure 15. Consistent with the extracted time trend in Figure 14, the unconditional average corporate net lending rate in our sample increased by about 3.5 percent of total sales over the 16 year period. More than two-third of the overall change can be explained by the increase in size of the average (publicly listed) firm. In addition, a significant 40 percent of the total change can be explained by the average increase in $R \& D$ intensity. ${ }^{12}$ Empirically, the expanding size and $R \& D$ spending of the average public firm can therefore account for most of the increase in the higher rate of excess saving we observe over this period. Among the remaining variables, the decline in average effective tax rates also played a significant role in boosting corporate net lending positions.

Almost all the underlying trends in explanatory variables are likely to be inter-

\footnotetext{
${ }^{12}$ We limit the decomposition exercise to firms with non-missing $R \& D$ spending at the start and end of the sample only, to avoid interpretation issues with missing data.
} 
related. To go beyond the reduced-form relationship estimated here, one needs to understand the deeper underlying drivers or these observed trends. The positive effect of firm size, and the negative effect of leverage and ETR indicate that trends documented elsewhere, in particular industrial concentration and rising market power of large firms - Autor et al. (2017), De Loecker and Eeckhout (2017) - , associated rise in corporate profits (Barkai, 2016), lower cost of capital (Chen et al. (2017), Dao et al. (2017)) and increased incentives and capacity for tax minimization (Zucman, 2014) all have contributed to increasing corporate saving/net lending across advanced economies.

\subsection{Discussion of mechanisms}

This paper has established a consistent positive relationship between the intensity of innovation activity and the propensity to retain earnings and accumulate cash by large firms in major advanced economies. However, our analysis does not directly point to the channel through which $R \& D$ affects cash and saving. There is an emerging literature that has proposed different hypotheses for why intangible capital (accumulated among others through innovation) can imply higher cash demand: for example, Falato et al. (2013) argue the lack of collateralizability of intangible capital reduces external debt capacity of financially constrained firms, prompting higher cash holding to finance future investment opportunities. The nature of intangible capital in terms of its financing profile or its capitalizability can also have implications for cash holding of the innovating firm, see Döttling et al. (2016) and Ma et al. (2014)). What most studies take as given though, is the time-series evolution and cross-sectional variation in intangible capital and $R \& D$ intensity, prompting the question of whether there are structural forces that drive both the incentive to innovate and the demand for liquidity. Most likely, technology and/or globalization play an important role in this context. There is a rapidly evolving literature on the impact of globalization on innovation activity (Autor et al. (2016), Bloom et al. (2016)), and work by Adler et al. (2017) which shows that globalization, by boosting incentives to engage in risk-enhancing innovation, can jointly raise innovation activity and cash

CInternational Monetary Fund. Not for Redistribution 
holding particularly among export-oriented firms. However, technology and globalization likely are not the only drivers for the corporate saving trends documented in this paper.

If technology and globalization increase corporate profits and retained earnings through benign forces such as trade and intangible capital, then why are these profits not contested by new entrants but instead sustained over such a prolonged period of time? There is emerging evidence that profit shares have increased together with industrial concentration (see Autor et al. (2017), Barkai (2016)), consistent with our result that size is strongly correlated with profit/net lending rates and cash holding. What are the drivers of increasing concentration? Are they related to the innovation channel and if so, how? Has $R \& D$ and the nature of new technology enabled stronger concentration, or has policy action consolidating incumbent advantage led to inefficient concentration? Answering these questions will be crucial to understand drivers of the rise in concentration and corporate saving, and as shown in this paper, ultimately shed light on important, so far unexplored drivers of current accounts and external imbalances.

\section{Conclusion}

In this paper, we have combined various macro and micro level datasets on balance sheet positions and flows of funds of corporations to document the pervasive trend in rising corporate saving. This broad-based trend appears to be of structural nature and shows no sign of reversing. By and large, it is driven by increased ability of large, publicly listed firms across advanced economies to extract larger profits and expand in size over time while limiting payouts to shareholders and taxes. Moreover, such sustained gains in profitability have not spurred higher investment in new fixed capital, leaving firms instead with growing stocks of liquid assets on their balance sheets.

Similar firm-level characteristics and drivers are associated with rising cash positions and excess saving rates across advanced economies, with some important het- 
erogeneity across countries. Most notably, firms that register the strongest increase in both cash and saving also saw the largest gains in profitability, market valuation and $R \& D$ spending. At the same time, these firms limited dividend payout in favor of share buybacks, reduced leverage and managed to reduce their effective tax rates. The evidence therefore points at a number of potential causes for rising corporate saving to be explored - with technology, globalization, governance and tax management strategies likely all playing a role. ${ }^{13}$

Among the questions that remain unaddressed is why the household sector does not "pierce the corporate veil" and at least partially offset the increased corporate saving rate (Poterba et al. (1987)). If anything, such a "veil" seems to have thickened over time in many advanced economies, allowing corporate saving investment imbalances be translated into persistent current account surpluses, most notably in Germany, Netherlands, Korea and Japan. ${ }^{14}$ With capital income being much more concentrated among the population than labor income, reinforcing rising wealth inequality worldwide (see Zucman (2014)), it should not be surprising that higher corporate saving and net worth did not give rise to proportionately higher aggregate household consumption. As a result, the rise in corporate net lending may have contributed to larger current account surpluses in countries where wealth inequality is relatively high, and where the corporate profit share has risen at the expense of a declining labor income share (see Behringer and van Treeck (2018)). Addressing persistent global imbalances may therefore require policies that ensure competition and prevent inefficient concentration on the corporate side (antitrust, product market regulation), as well as policies that help alleviate income and wealth inequality on the household side (corporate income taxes, estate and wealth taxes).

\footnotetext{
${ }^{13}$ For example, weak corporate governance has been found to be correlated with high cash holdings in Japan, see Aoyagi and Ganelli (2014).

${ }^{14}$ In the US and UK on the other hand, the trend toward higher private (household and corporate) net lending has been offset by larger government net borrowing, leading to current account deficits on aggregate.
} 


\section{Figures}

Figure 1: Net Lending, Gross Saving and Capital Expenditure of Non-Financial Corporations Aggregated Across Countries

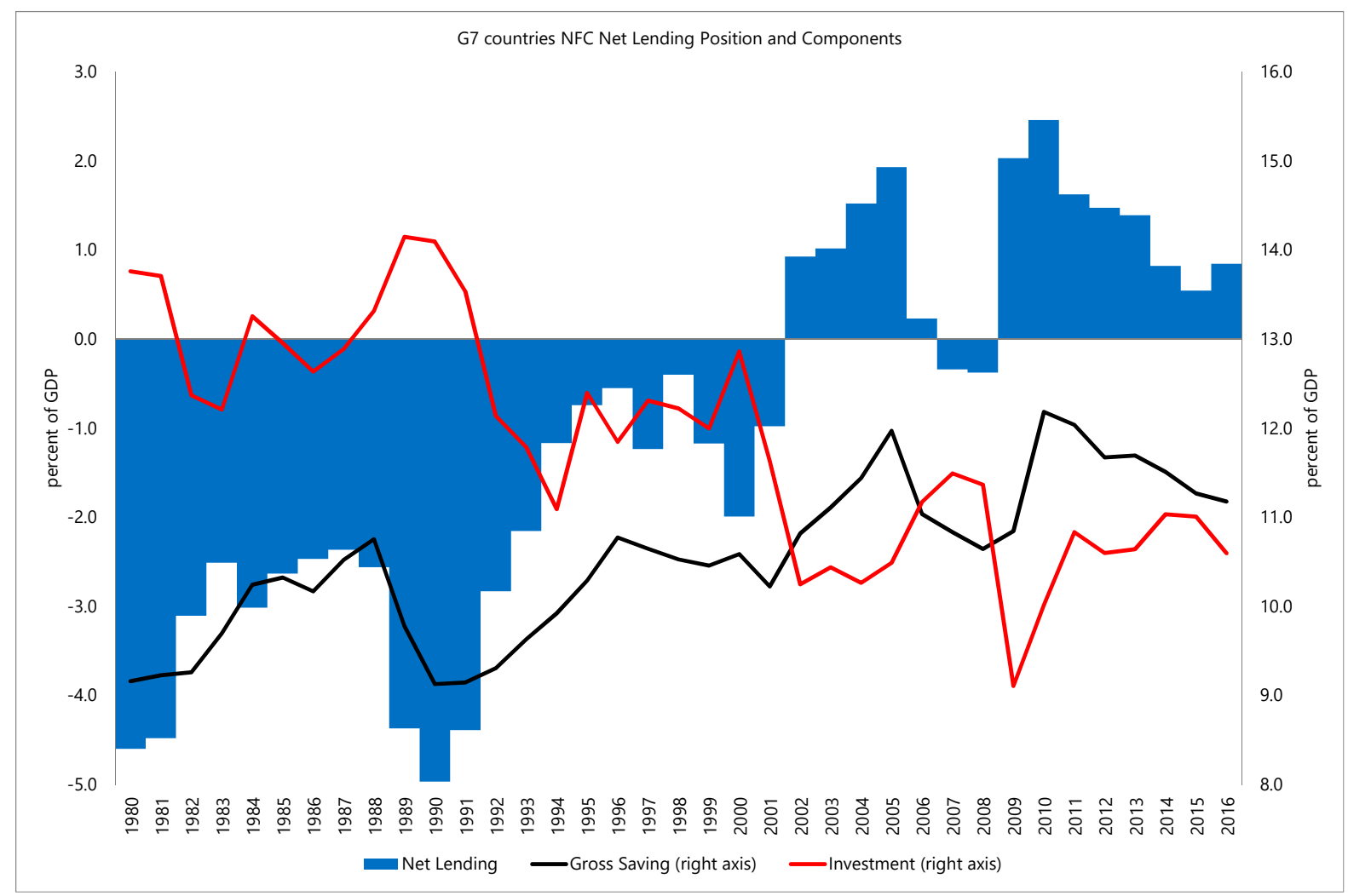

Source: Eurostat, National Income Accounts and IMF Staff calculations.

Note: Occasional discrepancies in Net Lending and its components are due to Capital Transfers. Net Lending, Gross saving and Investments are computed as GDP-weighted averages. Sectoral Data following SNA 2008 starts from 1995. For years prior to 1995, the investment and gross saving series are extended backwards using 2006 vintage that follows SNA 1993. Annual changes in investments and saving from SNA 1993 series are applied to current data to extend backwards until 1980, and net lending for this period is calculated as the balance of back-calculated gross saving over investments. SNA 1993 data is available for G6 countries, as it excludes Germany. 
Figure 2: Decomposition of Aggregate Net Lending over GDP
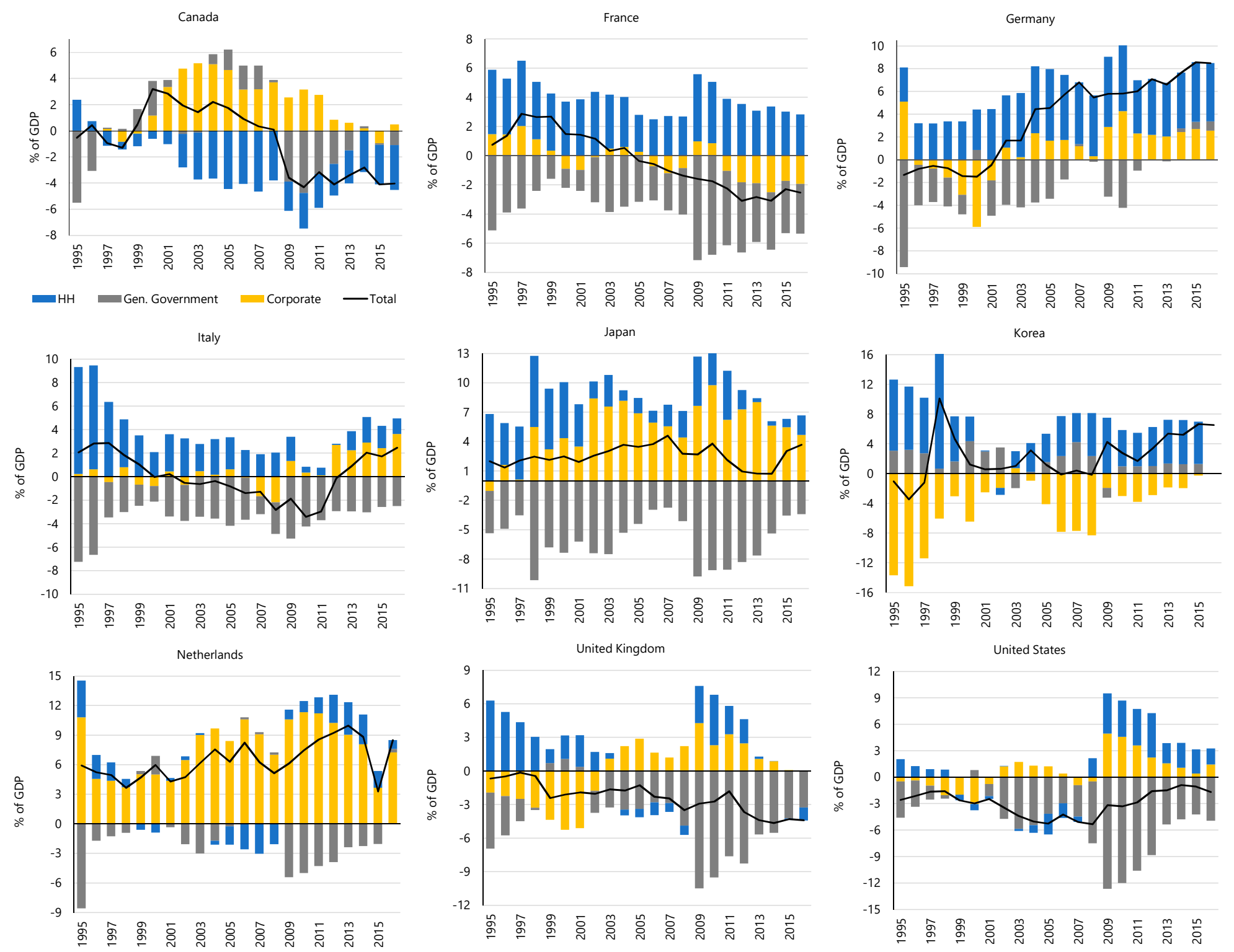

Source: Eurostat, National Sources and IMF Staff calculations 
Figure 3: Overview of the Non-Financial Corporate Sector: Gross Saving, Capital Expenditure, Net Lending

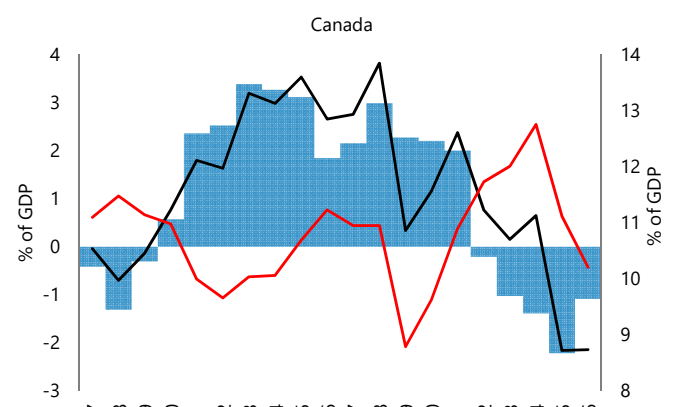

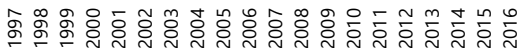

Nan Net Lending (LHS) _ Investments (RHS)

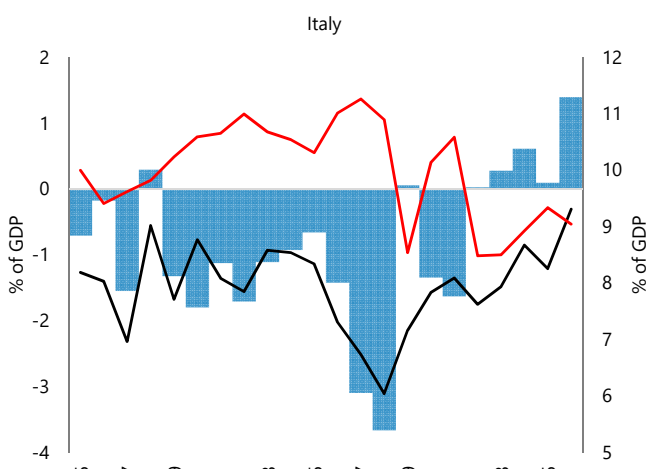

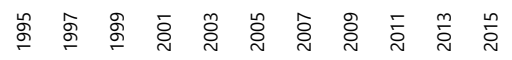

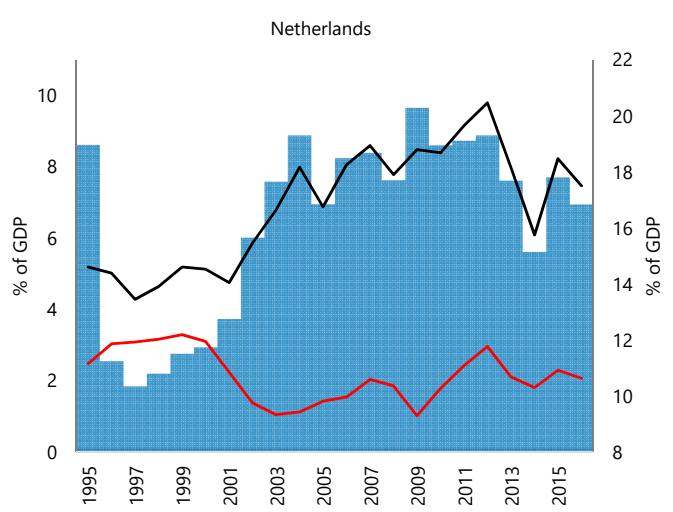

France

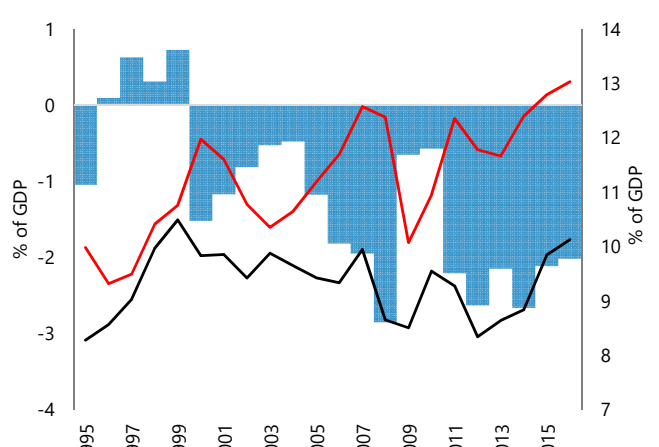

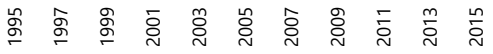

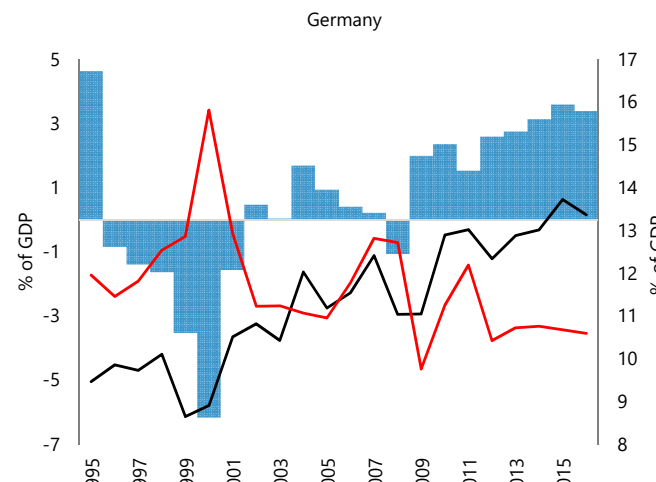

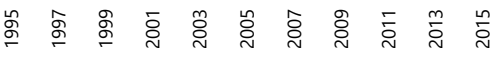
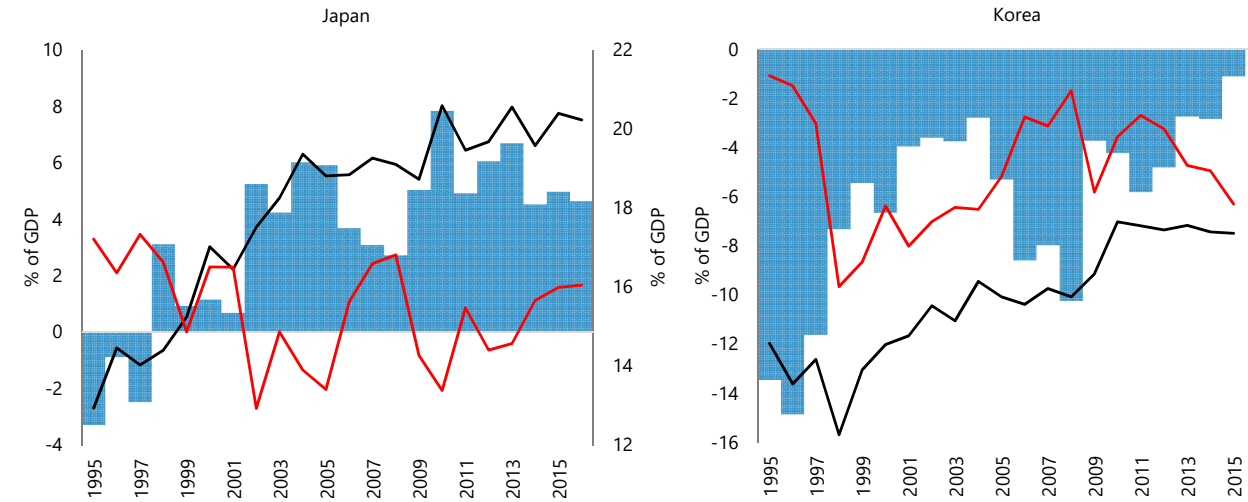

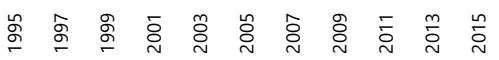
United States
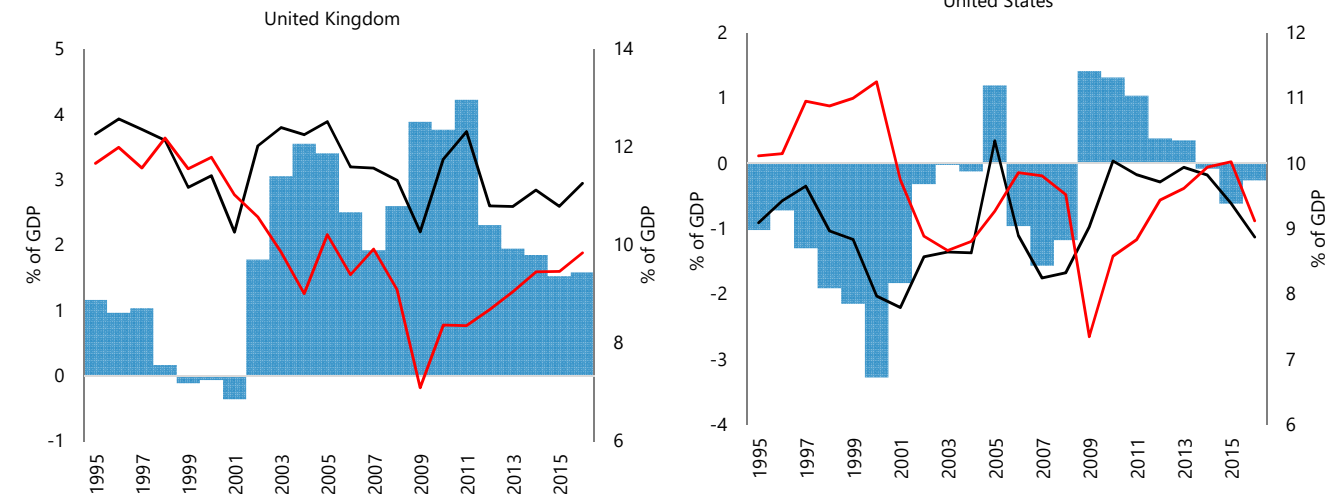

Source: Eurostat, National Sources and IMF Staff calculations. Note: Investments include net acquisition of non-produced non-financial assets. Occasional discrepancy in Net Lending and its components is caused by Capital Transfers. 
Figure 4: Decomposing change in gross saving rates into sources.

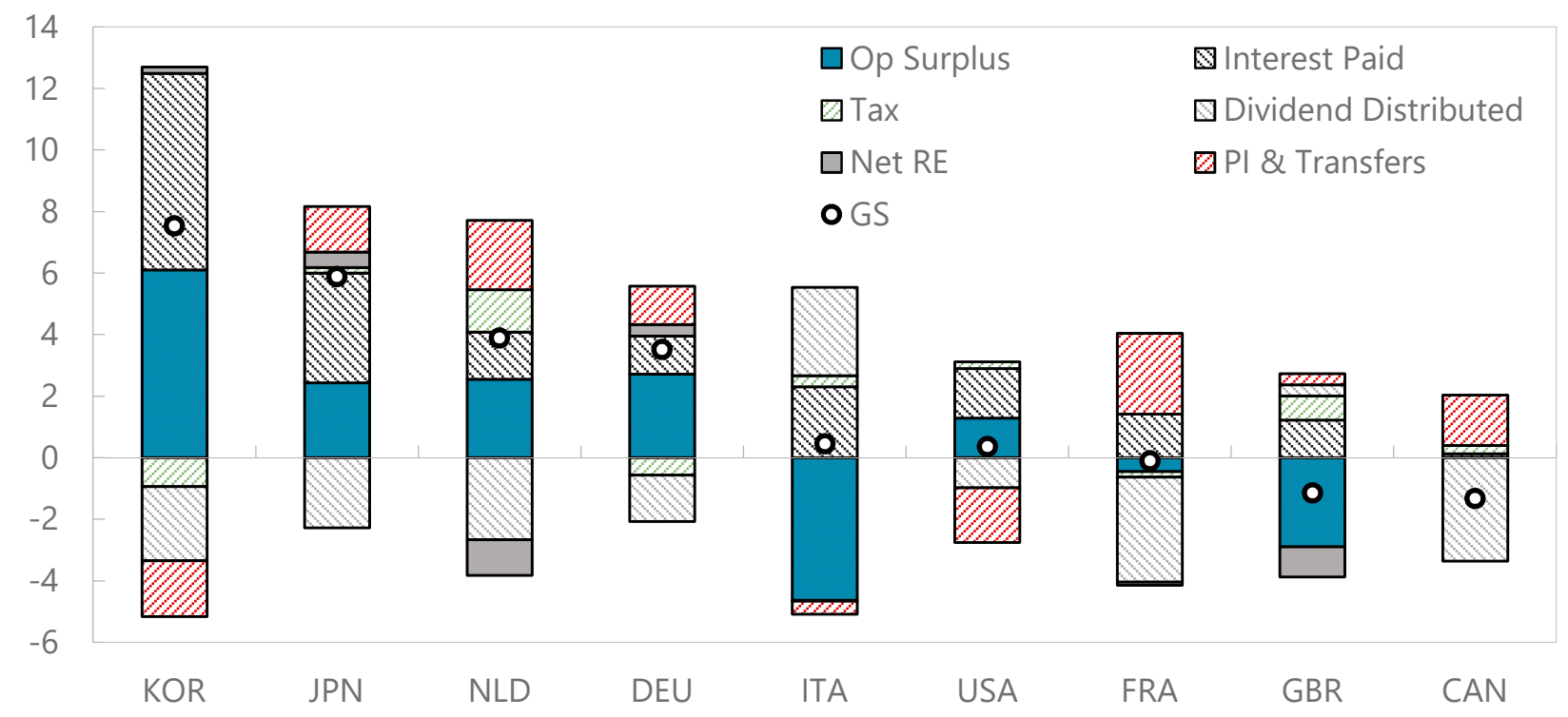

Note: Net RE is Net Retained Earnings on FDI. PI \& Transfers is the sum of Net Property Income and Net Transfers, where Net Property Income includes all income receivable on financial assets and rent excluding Net RE, and Dividend receivable.

Source: OECD, National Sources and IMF Staff calculations. Data on changes for all countries are from 1995 to 2016, in percent of GDP. 
Figure 5: Change in NFC operating surplus, main components
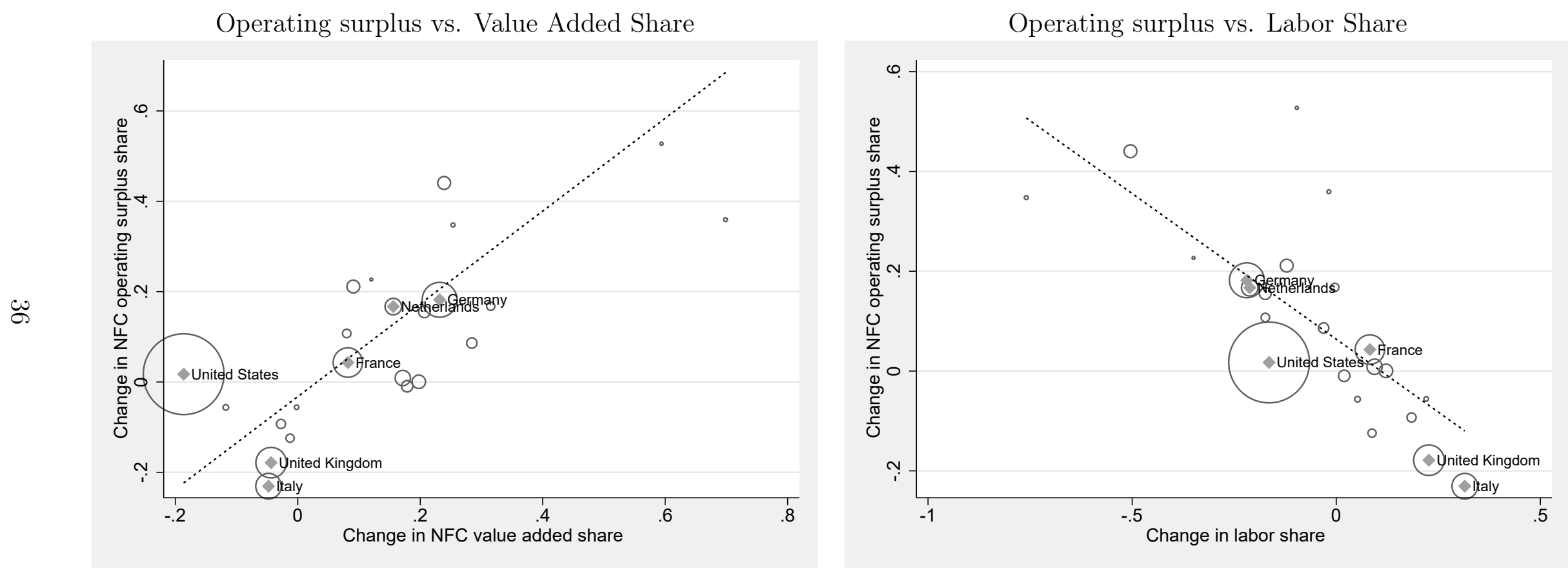

Source: OECD, national sources and IMF Staff calculations. Changes are yearly averages, taken over the entire sample period 1995-2016. Units are in percent of GDP. Bubbles size is proportional to nominal GDP in USD. G7+2 countries labeled. 
Figure 6: Correlation between net lending and NFA position

Canada

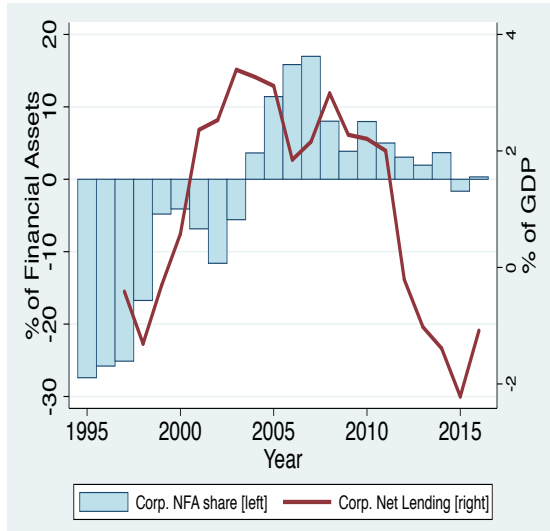

Italy

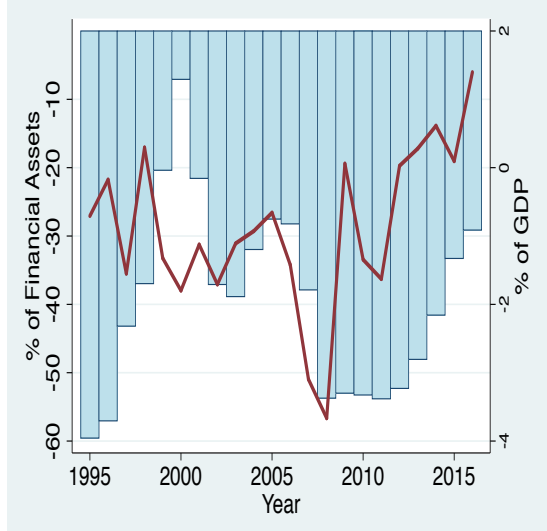

Netherlands

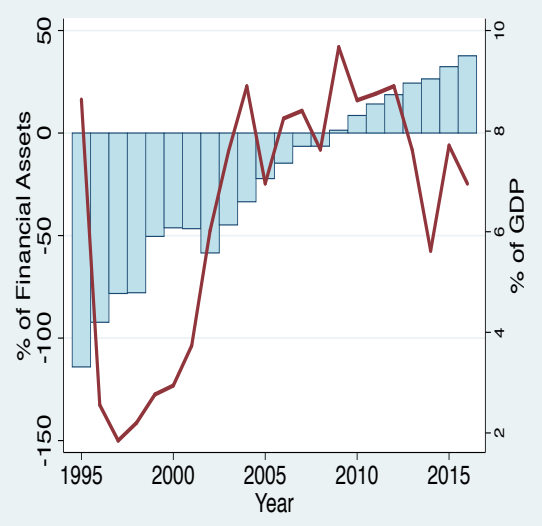

France

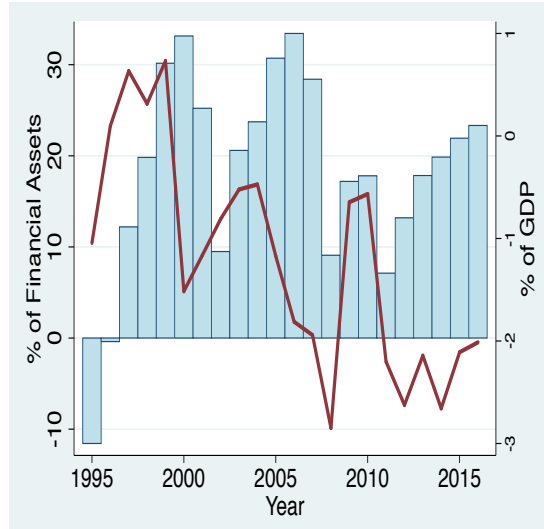

Japan

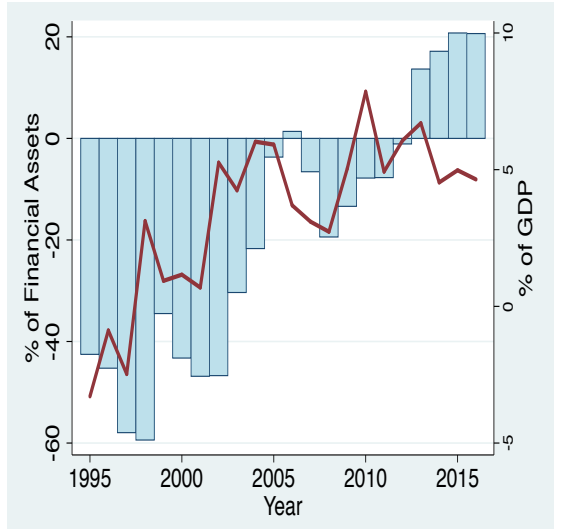

UK

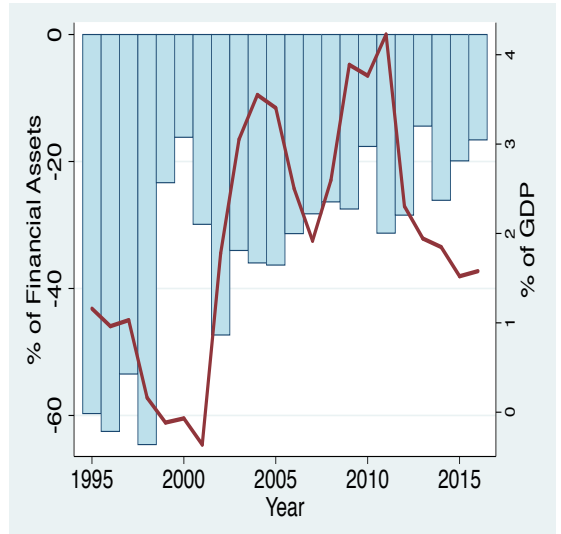

Germany

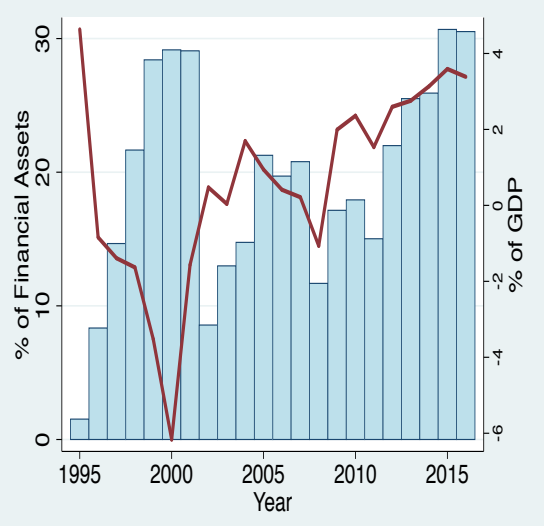

Korea

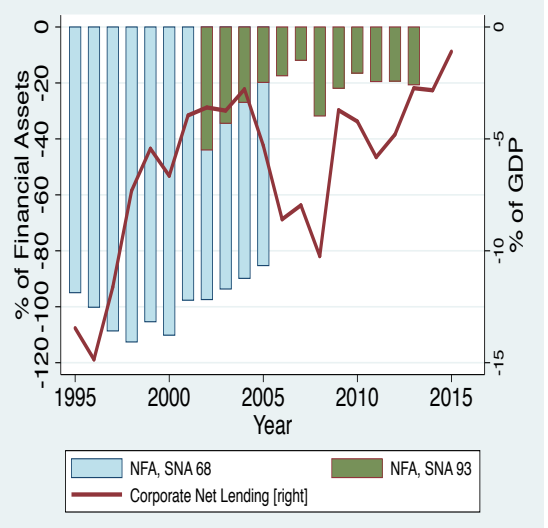

USA

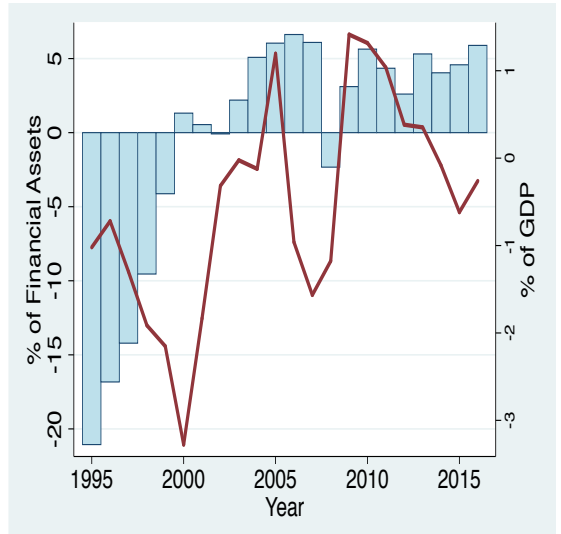

Source: Eurostat, National Sources and IMF Staff calculations 
Figure 7: Decomposition of the NFA Position of Non-Financial Corporations to Asset vs. Debt

Canada

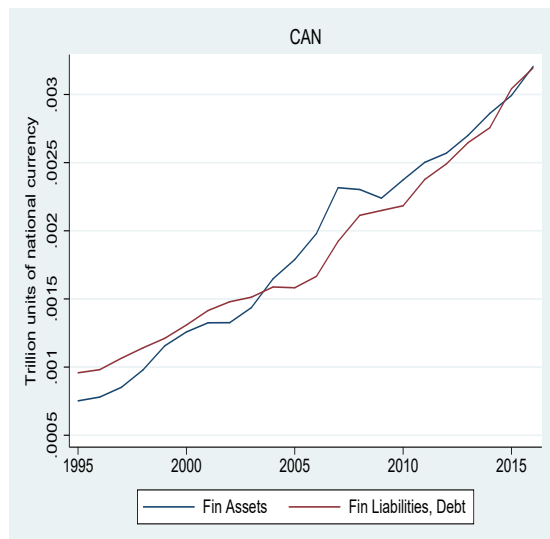

Italy

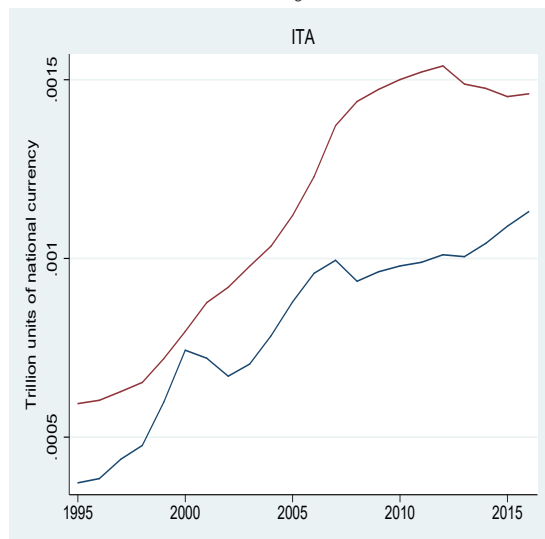

Netherlands

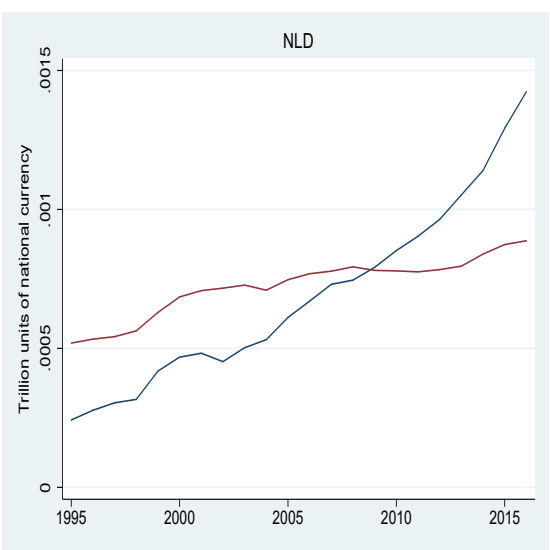

France

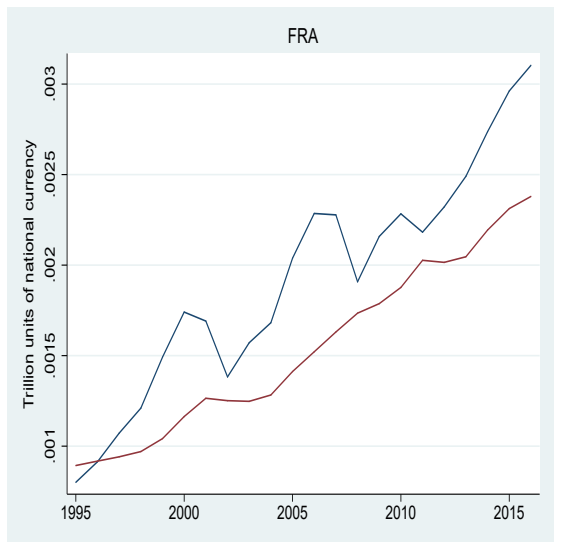

Japan

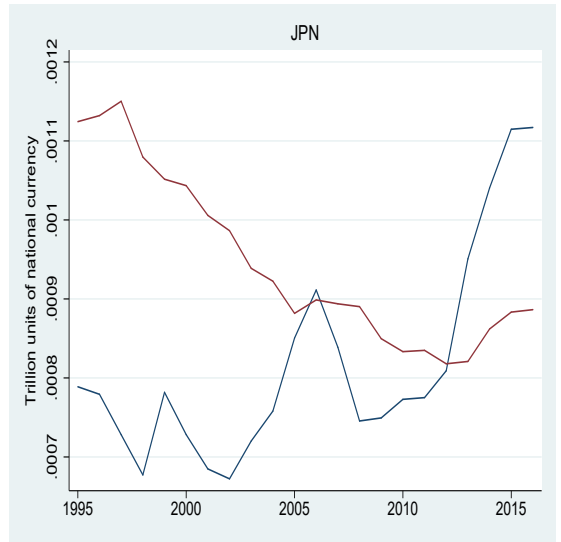

UK

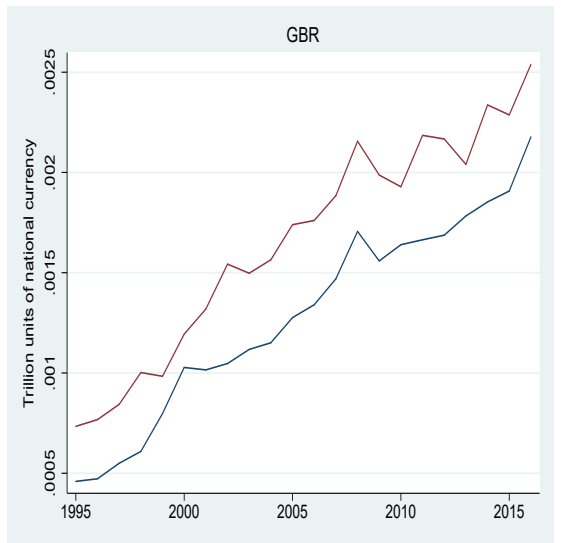

Germany

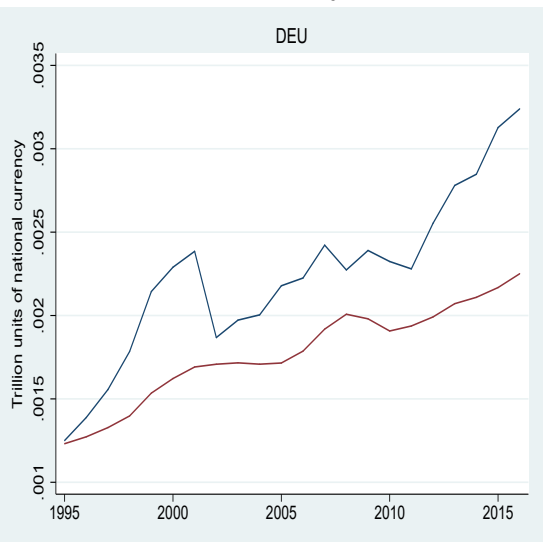

Korea

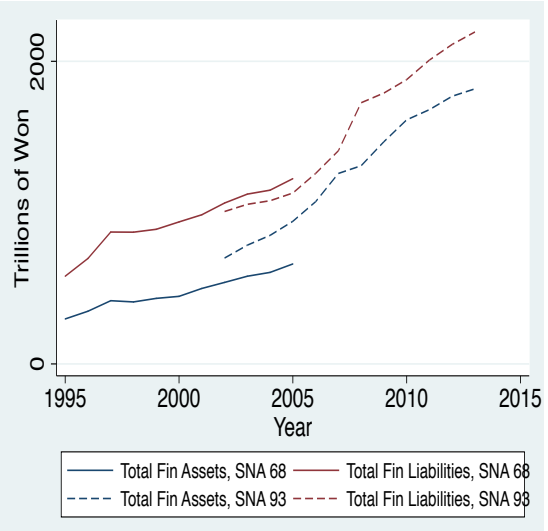

USA

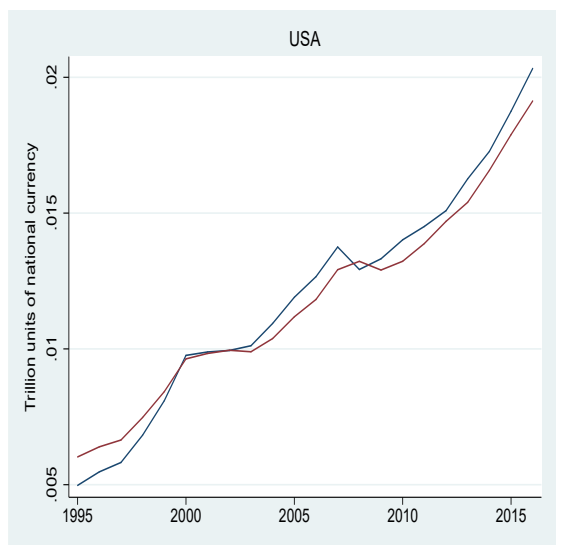

Source: Eurostat, National Sources and IMF Staff calculations 
Figure 8: Median Share of Cash And Liquid Assets over Total Assets by Sector
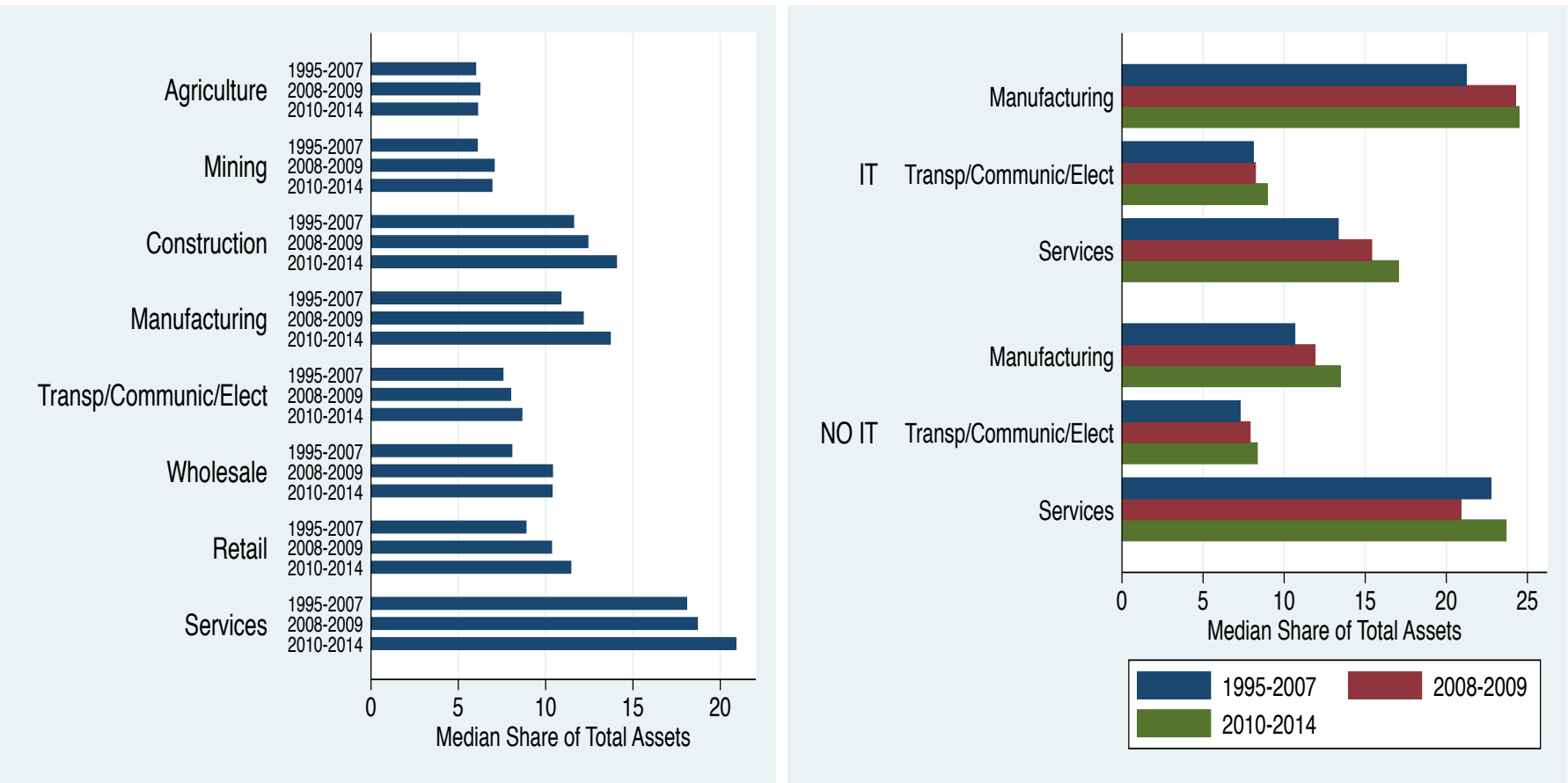

Source: Thompson Worldscope database.

Note: the left panel computes the median cash ratio over total financial assets for listed non-financial firms in Worldscope. The median share is computed by sector and for three sub-periods. The right panel instead computes the median share by sector grouped into IT-intensive and non-IT-intensive industries with classification as described in the text [check with Chiara]. 
Figure 9: Co-movements between Net Lending rates and Cash ratios.
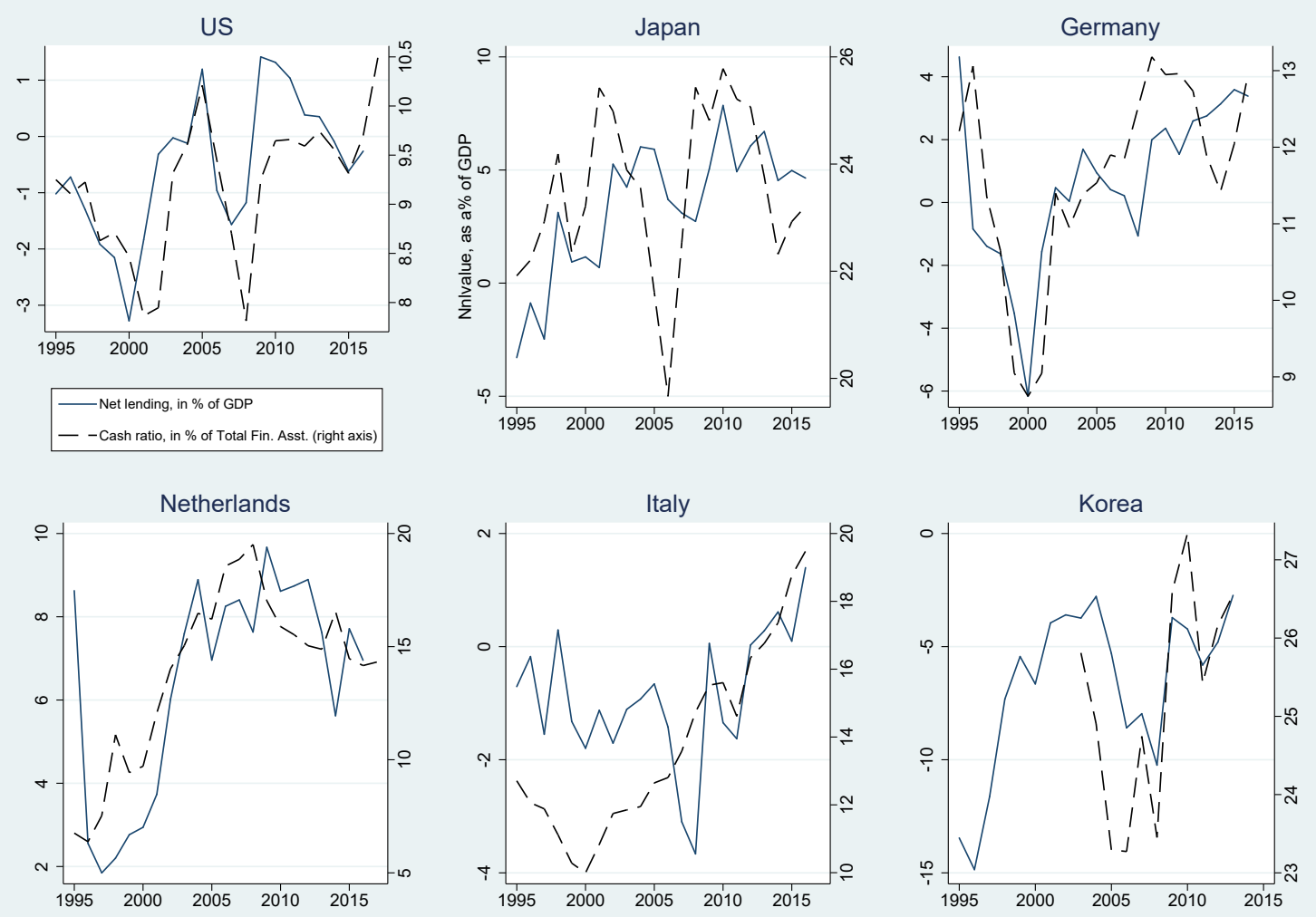

Source: Eurostat and National Sources 
Figure 10: Aggregate NFC saving (in pct of GDP) and aggregated firm-level saving (in pct of sales).
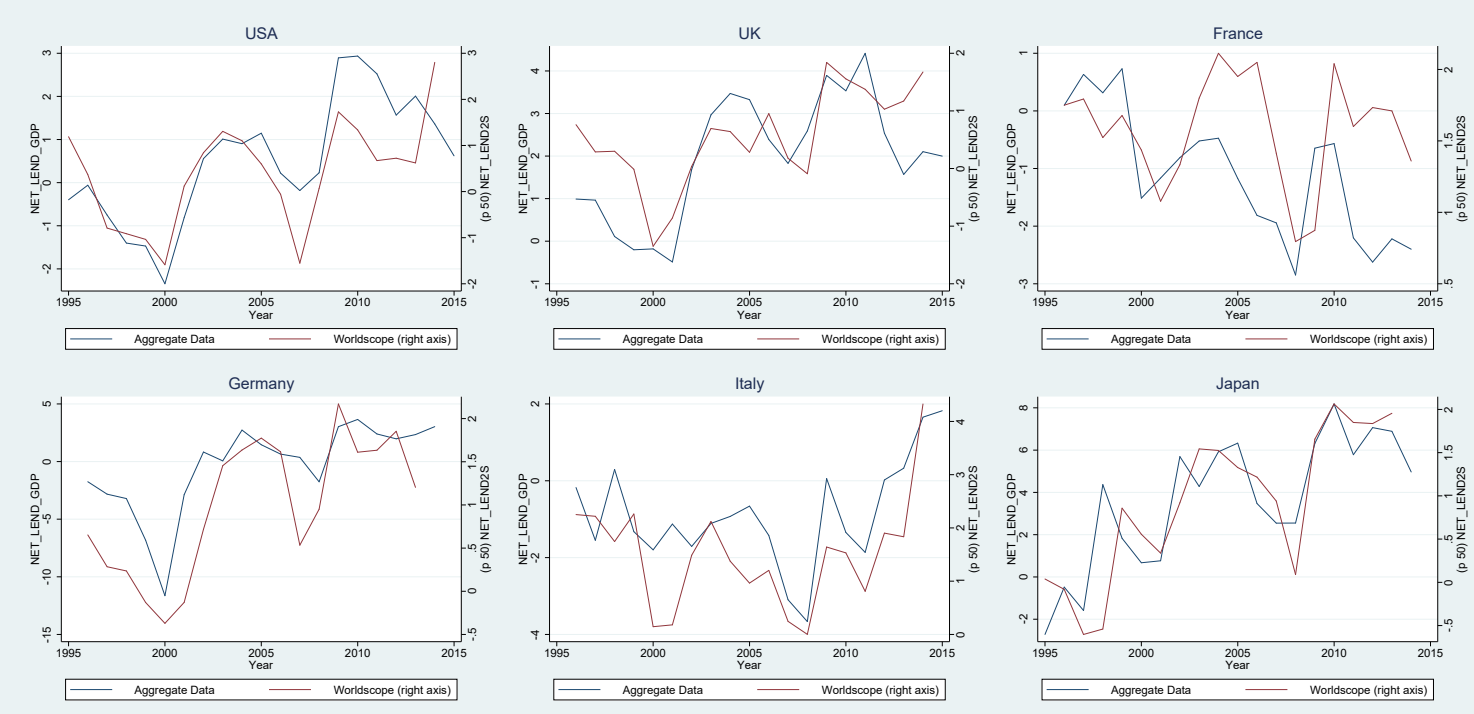

Italy
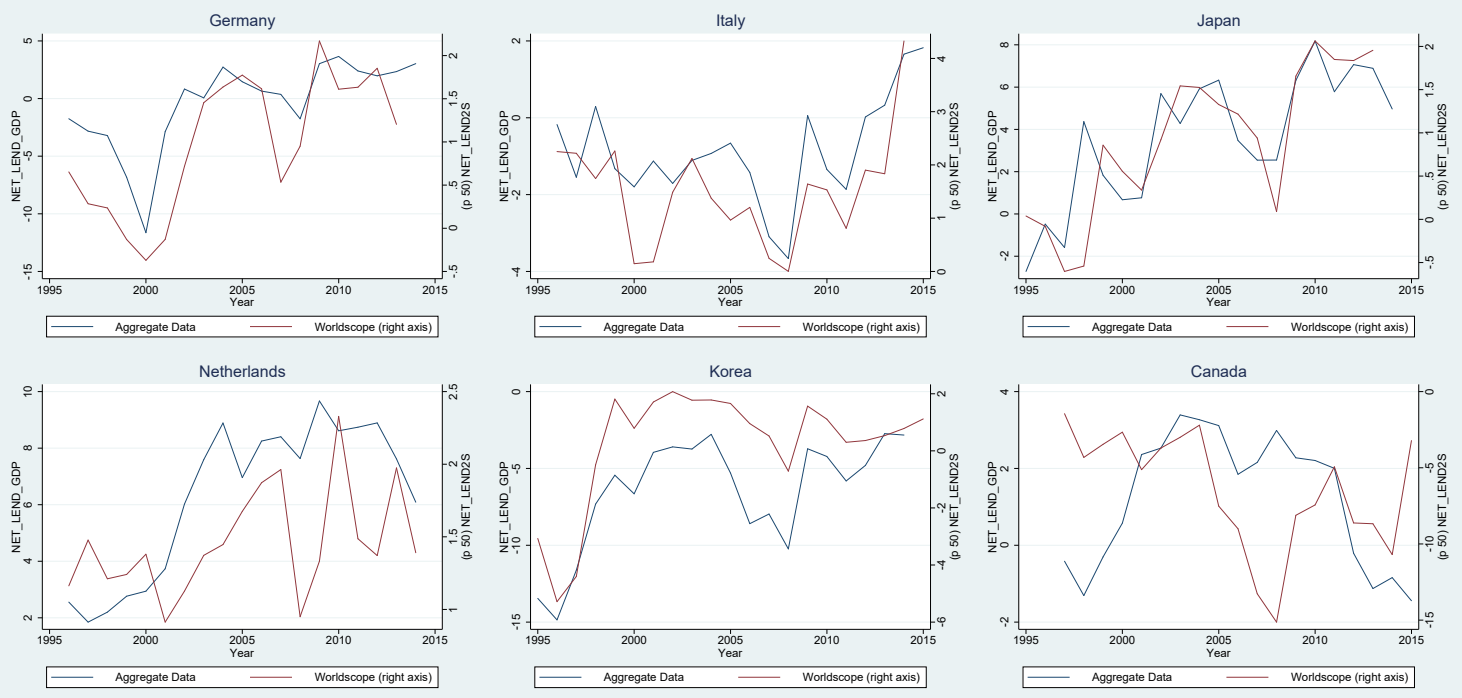

Source: Thomson Reuters Worldscope, Eurostat and National Sources. Aggregate NFC net lending (in percent of GDP) is from sectoral national accounts data. Aggregated firm-level excess saving rate (in percent of sales) is the median net lending rate among all firms (excluding finance and insurance) in each country for a given year. 
Figure 11: Shifts in median cash ratios by size quintiles.

Canada

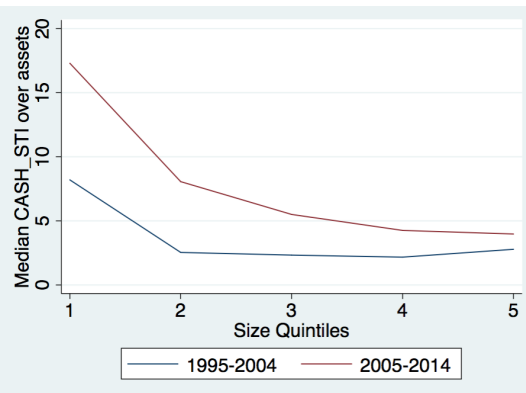

Italy

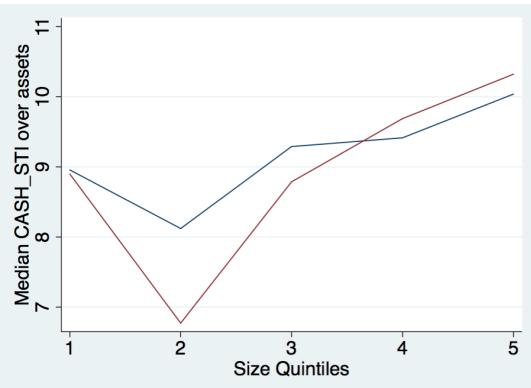

Netherlands

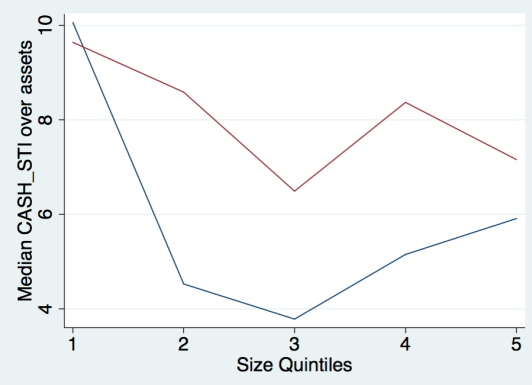

France

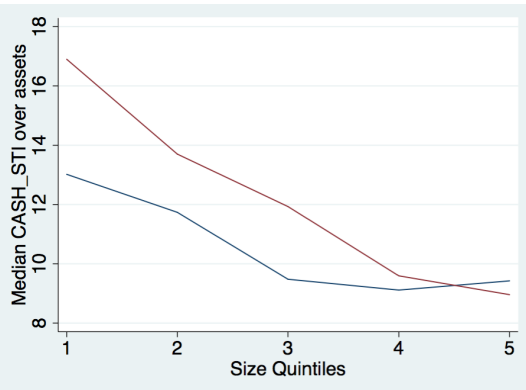

Japan

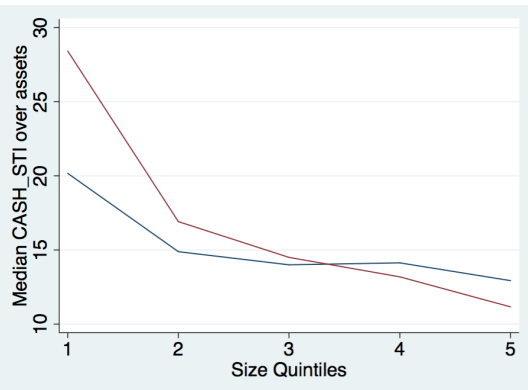

UK

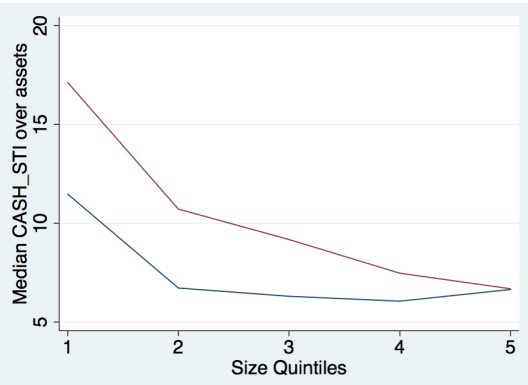

Germany

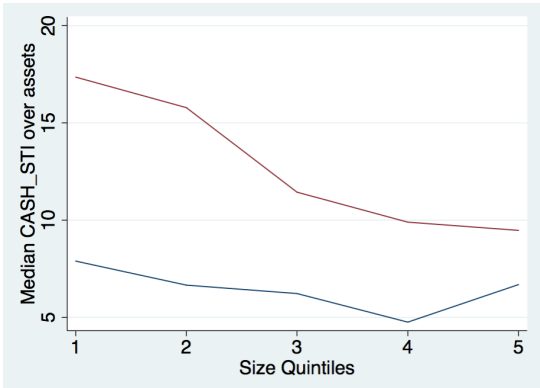

Korea

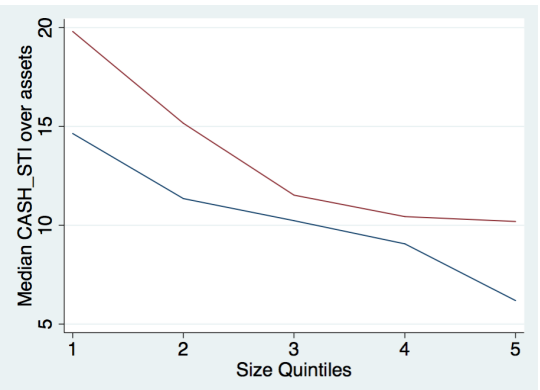

USA

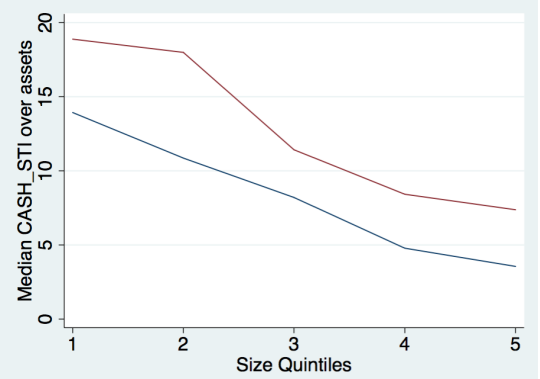

Source: Thompson Worldscope database and authors' calculations. 
Figure 12: Shifts in median net lending rates by size quintiles.

Canada

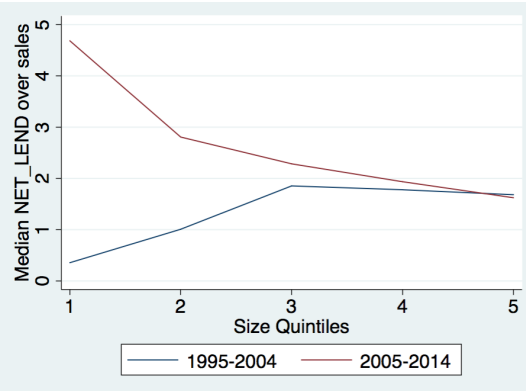

Italy

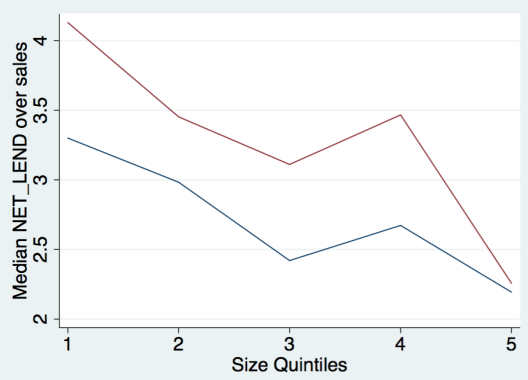

Netherlands

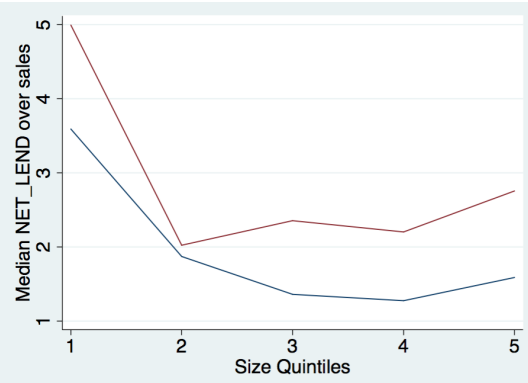

France

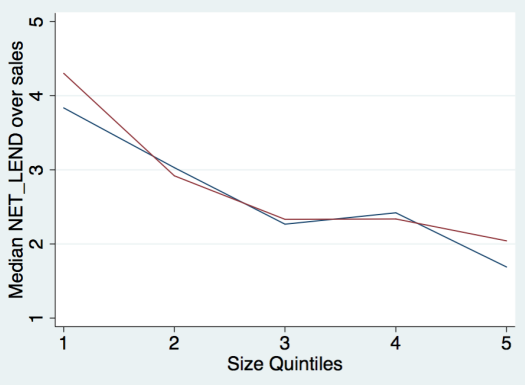

Japan

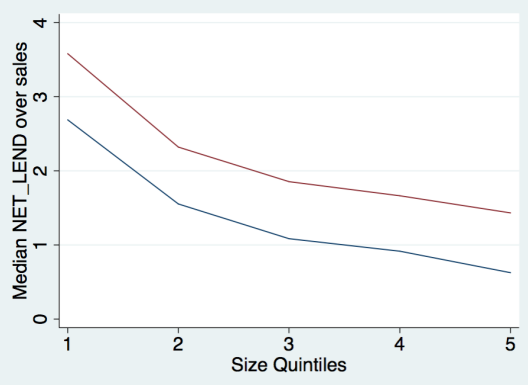

UK

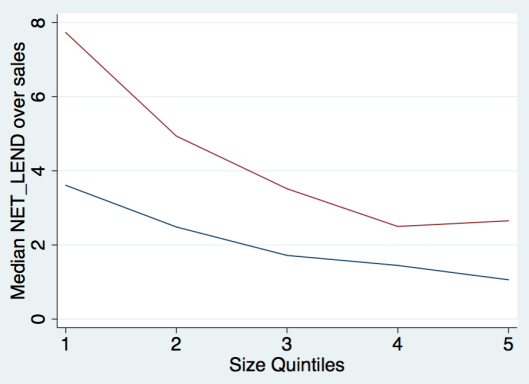

Germany

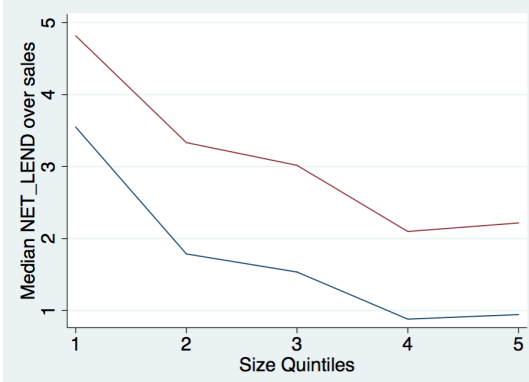

Korea

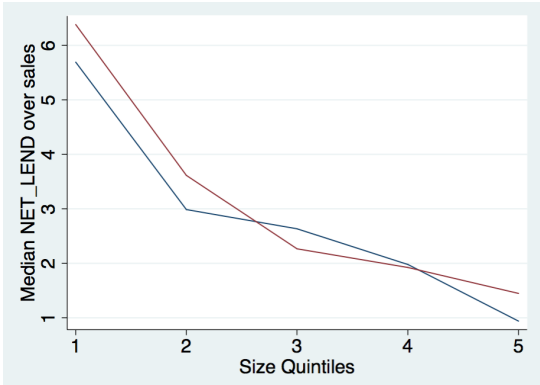

USA

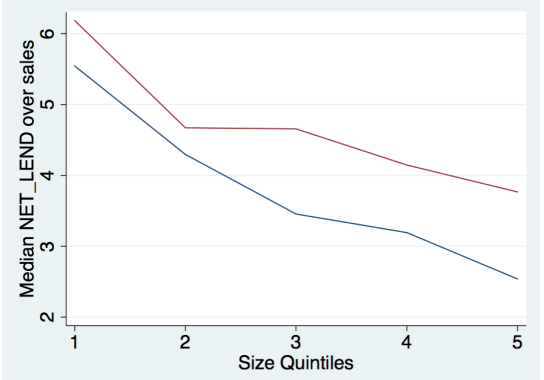

Source: Thompson Worldscope database and authors' calculations. 
Figure 13: Decomposition of cumulative change in average cash ratio: intensive (within-sample) vs. extensive (composition) margin.
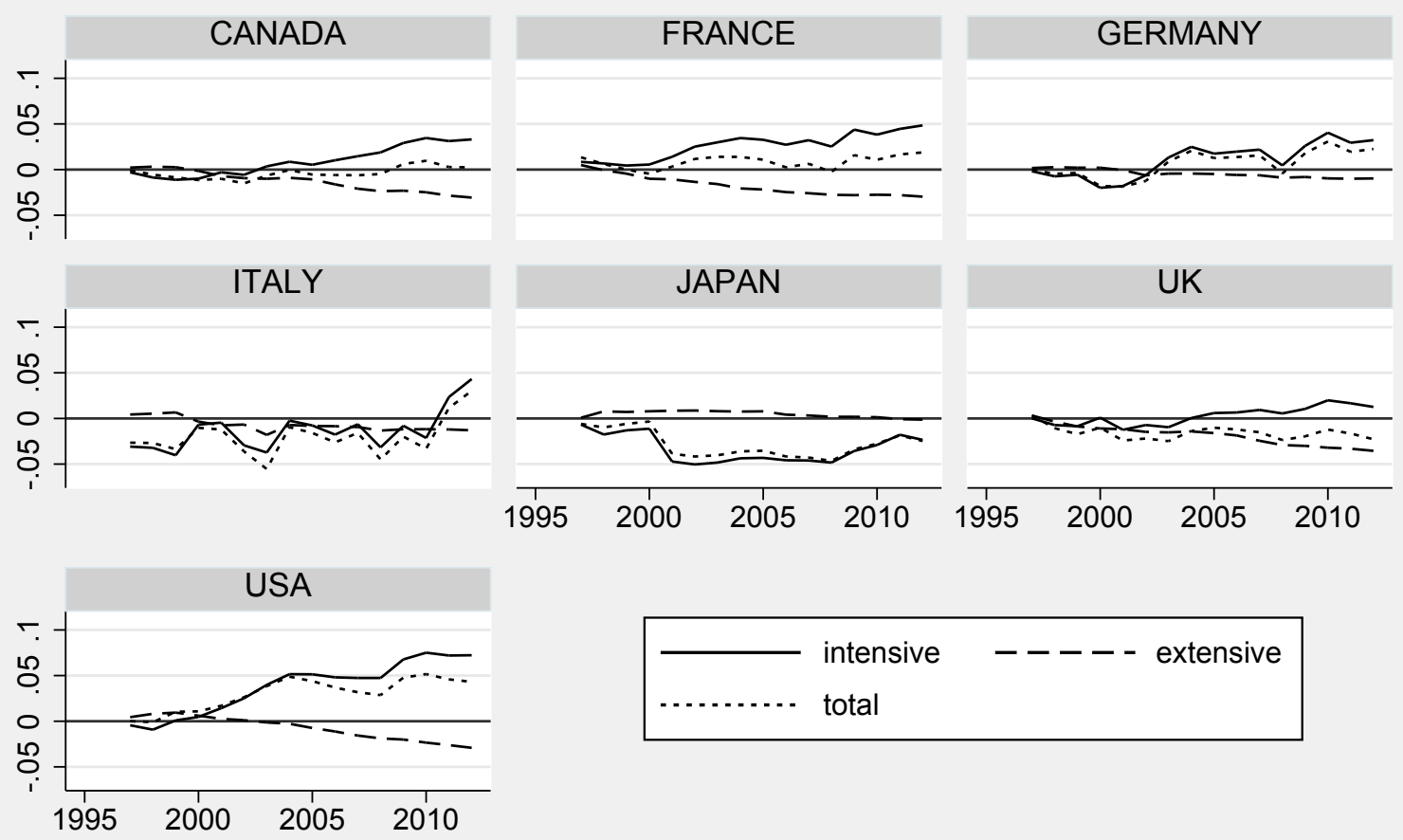

Source: Thompson Worldscope database. For each country, the contribution from firms' entry and exit (extensive margin) on the average cash ratio as well as the contribution from incumbent firms' cash ratio changes (intensive margin) on the average are shown. The decomposition is based on equation (6) in the text. 
Figure 14: Time trends in corporate net lending

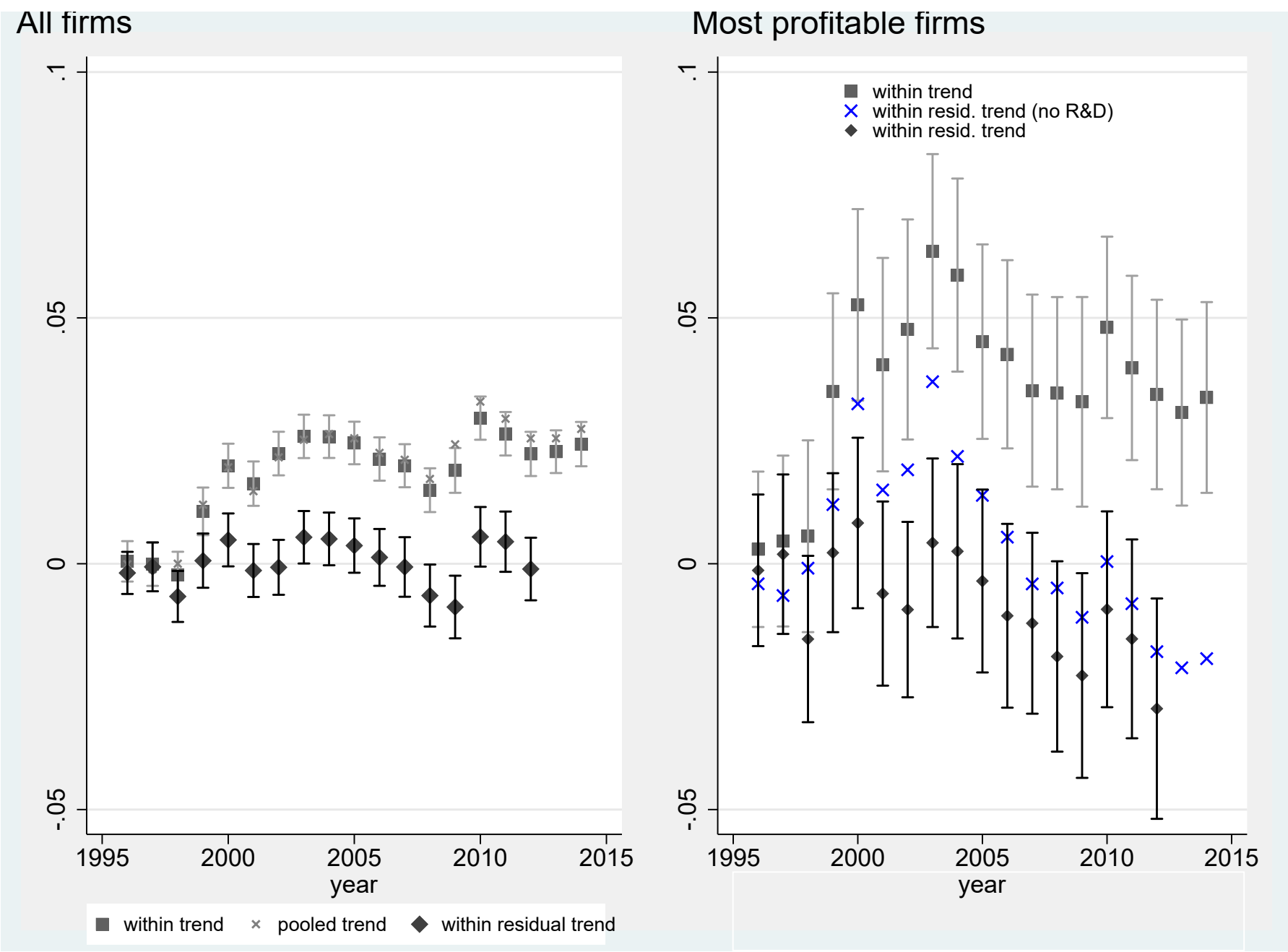

Source: Thompson Worldscope database and author's calculation. Pooled trend is extracted by regressing the firm-level net lending rate (in percent of total sales) in a country and year fixed effect $(\mathrm{FE})$, the within trend controls also for firm fixed effects, and the resulting coefficients estimates and confidence bands for the time FE are plotted. The residual time trend shows the estimated time FE while controlling for all other explanatory variables in column 4 of Table 7 . In all cases, only firms with at least 15 years of observations and non-missing $R \& D$ spending data are included. Right panel shows the subset of firms with profit rates (measured by net margin in percent of revenues) in the top quintile of the sample (as in column 6 of Table 7). 
Figure 15: Explaining corporate excess saving.

\section{Decomposition of average long-run change in corporate net lending} (1996-2012, non-missing R\&D firms only)

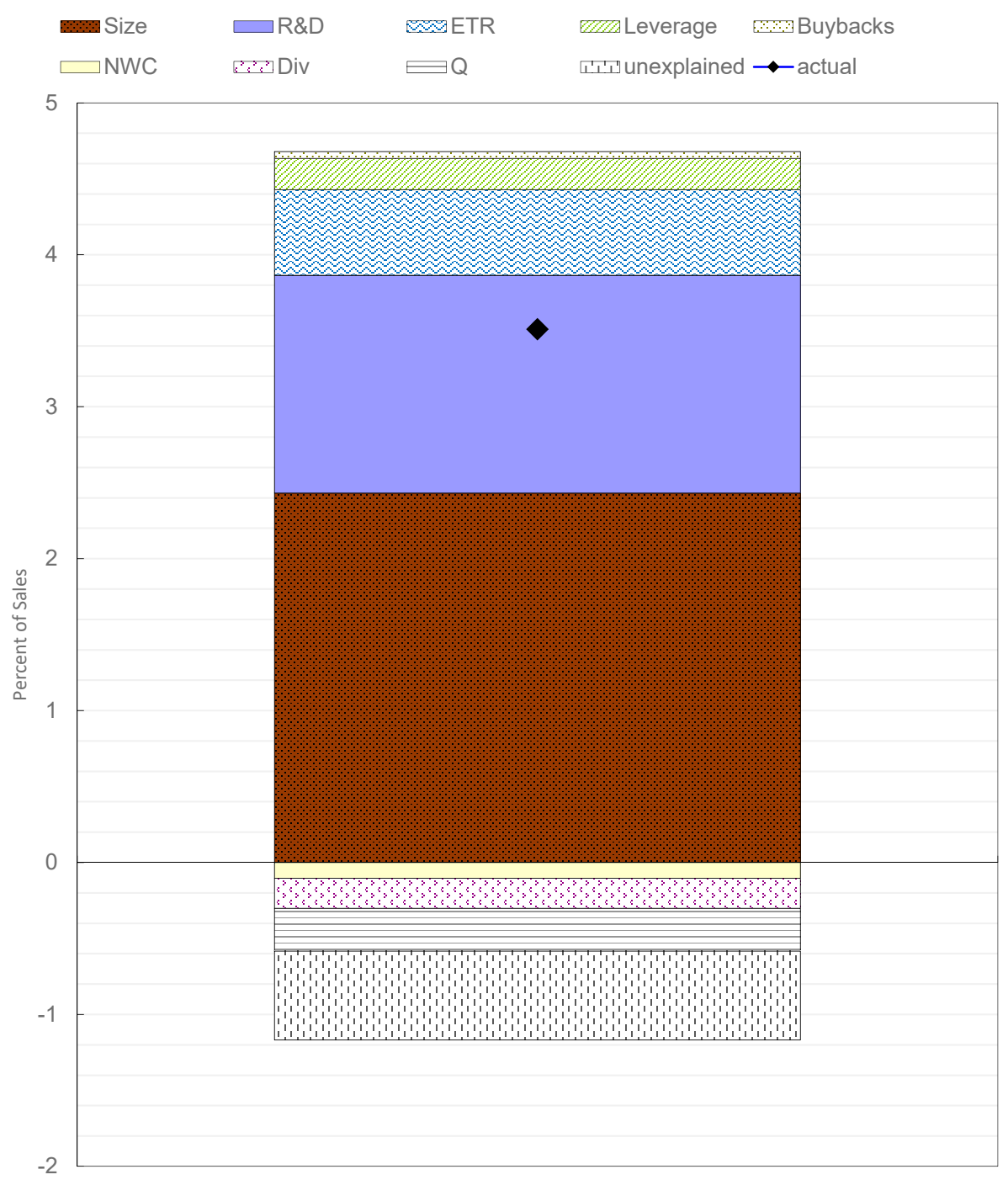

Sources: Worldscope (Thomson Reuters), authors' calculations

Note: The decomposition is performed on the sample of firms in G7+2 countries over 1995-2012 for which $R \& D$ spending data is non-missing in the first and last year of the sample. The coefficients used to compute the contribution of each regressor are based on the regression result in column 5 of Table 8. 
Table 1: Use of net lending from national accounts

Dep. Var: Net lending (in \% of GDP)

(1)

$(2)$

(3)

(4)

Pooled

Within

\begin{tabular}{lllll} 
& \multicolumn{3}{c}{ Cosolidated } & Unconsolidated \\
\cline { 2 - 4 } Cash ratio & $0.134^{* * *}$ & $0.238^{* * *}$ & $0.240^{* * *}$ & $0.305^{* * *}$ \\
Equity assets & $(0.032)$ & $(0.055)$ & $(0.078)$ & $(0.098)$ \\
& $0.079^{*}$ & $0.213^{* * *}$ & $0.222^{* * *}$ & $0.177^{* * *}$ \\
Loan/Debt assets & $(0.042)$ & $(0.044)$ & $(0.053)$ & $(0.056)$ \\
& $0.357^{* * *}$ & $0.139^{* *}$ & 0.124 & $0.159^{*}$ \\
Account receivables & $(0.035)$ & $(0.060)$ & $(0.075)$ & $(0.087)$ \\
& $(0.203)$ & $(0.122)$ & $(0.144)$ & $(0.098)$ \\
Debt repayment & $0.200^{* * *}$ & $0.166^{* * *}$ & $0.118^{*}$ & $0.121^{*}$ \\
Share buyback & $(0.042)$ & $(0.043)$ & $(0.062)$ & $(0.073)$ \\
Country FE & $0.196^{* * *}$ & $0.175^{* * *}$ & $0.111^{*}$ & 0.061 \\
Year FE & $(0.056)$ & $(0.048)$ & $(0.063)$ & $(0.062)$ \\
N & No & Yes & Yes & Yes \\
R-sq & No & No & Yes & Yes \\
& 105 & 105 & 105 & 155 \\
& 0.636 & 0.476 & 0.543 & 0.464
\end{tabular}

Notes: Column 1 is pooled, column 2-4 within-country regression. Cash, equity and loan/debt assets are in percent of total financial assets. Debt repayment and share buyback are net negative transactions in debt and equity liability, in percent of total financial assets. Column 1-4 use consolidated balance sheet data, column 5 uses unconsolidated balance sheet data (preferred method in system of national accounts and available for wider sample). Countries in the sample include: Germany, Netherlands, Kora, Japan, France, US, UK, Canada 1995-2016 (except Korea only 2008-2016). Source: OECD National Accounts and national sources. 
Table 2: Coverage in Worldscope relative to sectoral national accounts (in percent, 1999-2014 average).

\begin{tabular}{lrrr} 
country & Gross operating surplus & Gross saving & Capital expenditure \\
\hline Italy & 27.7 & 34.3 & 25.1 \\
Germany & 33.4 & 41.1 & 39.6 \\
Canada & 43.8 & 43.4 & 68.1 \\
Japan & 44.3 & 36.8 & 39.7 \\
Korea & 56.5 & 59.2 & 46.1 \\
United States & 64.4 & 58.5 & 50.0 \\
Netherlands & 67.4 & 49.8 & 69.2 \\
France & 68.8 & 58.7 & 47.1 \\
United Kingdom & 99.6 & 74.9 & 79.9 \\
\hline \hline average & 56.2 & 50.7 & 51.7
\end{tabular}

Note: For each country and variable, the average ratio of the aggregated value from Worldscope data relative to the corresponding value recorded in the income accounts of the non-financial corporate sector as part of the system of national accounts over 1999-2014 is given (in percent). Gross operating profits are measured as earnings before interest, tax, amortization and depreciation at the firm level. Gross saving refers to undistributed gross profits and is defined as in equation (3) in the text. 
Table 3: Pooled firm-level regressions
(1)
(2)
(3)
(4)
(5)

Cash ratio

Net lending rate

trend

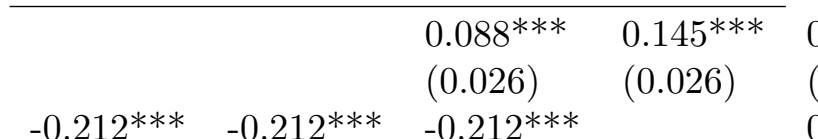

$0.038^{* *}$

nwc

$(0.013)$

$(0.013)$

(0.013)

$(0.017)$

$0.020 * * *$

size

$-0.009^{* * *}$

$-0.009^{* * *} \quad-0.009^{* * *}$

$(0.006)$

(0.001)

(0.001)

(0.001)

$0.002^{* * *}$

leverage

$-0.362^{* * *}$

$-0.362^{* * *}$

$-0.361^{* * *}$

$(0.001)$

(0.013)

(0.014)

(0.013)

$-0.068^{* * *}$

$\begin{array}{lll}-0.024^{* * *} & -0.025^{* * *} & -0.025^{* * *}\end{array}$

$(0.009)$

div. status

$(0.004)$

(0.004)

(0.004)

$-0.024^{* * *}$

profit

$0.048^{* * *}$

$0.048^{* * *}$

$0.050^{* * *}$

$(0.003)$

(0.017)

$(0.017)$

(0.017)

$0.062^{* * *}$

Tobin's Q

$0.010^{* * *}$

$0.011^{* * *}$

$0.010^{* * *}$

$(0.021)$

(0.004)

$(0.004)$

(0.004)

$0.010^{* * *}$

CF vol.

$0.368^{* * *}$

$0.368^{* * *}$

$0.371^{* * *}$

$(0.001)$

(0.054)

(0.054)

(0.054)

0.049

EPU index

$0.006^{* * *}$

$-0.016^{* * *}$

0.002

$(0.043)$

$(0.002)$

(0.005)

(0.002)

0.002

Share of foreign sales

$0.070^{* * *}$

$0.069 * * *$

$0.069^{* * *}$

$(0.002)$

$(0.006)$

(0.006)

(0.006)

$0.012^{* * *}$

(0.004)

$R \& D$ intensity

$0.122^{* * *}$

$0.122^{* * *}$

$0.122^{* * *}$

$0.221^{* * *}$

(0.010)

(0.010)

(0.010)

(0.033)

IPO year

$0.012^{* * *}$

$0.012^{* * *}$

$0.012^{* * *}$

0.001

(0.003)

(0.003)

(0.003)

Country FE

$\mathrm{Y}$

$\mathrm{Y}$

$\mathrm{Y}$

(0.003)

Year FE

$\mathrm{N}$

$\mathrm{Y}$

Y

$\mathrm{Y}$

37424

37424

$\mathrm{N}$

$\mathrm{N}$

R-sq

0.422

0.424

37424

0.422

37424

30211

0.118

Notes: The dependent variable in columns 1-4 is the cash and short-term investment to book asset ratio, in column 5 is the net lending to sales ratio, defined as net income gross of depreciation, minus dividends paid, in percent of sales. Both variables are winsorized at 1 percent. Standard errors in parenthesis are clustered at the firm level. Source: Thompson Reuters Worldscope. 
Table 4: Within-firm and first-difference regressions

\begin{tabular}{|c|c|c|c|c|c|}
\hline & $(1)$ & $(2)$ & $(3)$ & $(4)$ & $(5)$ \\
\hline & \multicolumn{5}{|c|}{ Dep. Var: Cash ratio } \\
\hline & level & $\log$ & level: w/o US & FD & FD: w/o US \\
\hline \multirow[t]{2}{*}{$R \& D$ intensity } & $0.047 * * *$ & $0.106^{* * *}$ & $0.066^{* * *}$ & $0.026^{* * *}$ & $0.037^{* *}$ \\
\hline & $(0.007)$ & $(0.023)$ & $(0.019)$ & $(0.007)$ & $(0.015)$ \\
\hline \multirow[t]{2}{*}{ size } & $-0.018^{* * *}$ & $-0.097^{* * *}$ & $-0.020^{* * *}$ & $-0.000^{*}$ & $-0.001^{* * *}$ \\
\hline & $(0.003)$ & $(0.024)$ & $(0.005)$ & $(0.000)$ & $(0.000)$ \\
\hline \multirow[t]{2}{*}{ nwc } & $-0.256^{* * *}$ & $-1.679^{* * *}$ & $-0.221^{* * *}$ & $-0.240^{* * *}$ & $-0.196^{* * *}$ \\
\hline & $(0.014)$ & $(0.105)$ & $(0.015)$ & $(0.012)$ & $(0.014)$ \\
\hline \multirow[t]{2}{*}{ profit } & $0.123^{* * *}$ & $0.907 * * *$ & $0.147^{* * *}$ & $0.171^{* * *}$ & $0.204^{* * *}$ \\
\hline & $(0.012)$ & $(0.089)$ & $(0.017)$ & $(0.010)$ & $(0.013)$ \\
\hline \multirow[t]{2}{*}{ leverage } & $-0.193^{* * *}$ & $-1.698^{* * *}$ & $-0.174^{* * *}$ & $-0.094^{* * *}$ & $-0.061^{* * *}$ \\
\hline & $(0.014)$ & $(0.103)$ & $(0.017)$ & $(0.012)$ & $(0.016)$ \\
\hline \multirow[t]{2}{*}{ div. status } & 0.004 & $-0.043^{*}$ & 0.004 & $-0.003^{*}$ & -0.002 \\
\hline & $(0.003)$ & $(0.025)$ & $(0.003)$ & $(0.002)$ & $(0.002)$ \\
\hline \multirow[t]{2}{*}{ Foreign sales shr } & 0.007 & $0.070 * *$ & 0.009 & -0.008 & -0.006 \\
\hline & $(0.005)$ & $(0.029)$ & $(0.006)$ & $(0.005)$ & $(0.006)$ \\
\hline \multirow[t]{2}{*}{ Tobin's Q } & $0.005^{* * *}$ & $0.038^{* * *}$ & $0.007^{* * *}$ & $0.003^{*}$ & $0.005^{* * *}$ \\
\hline & $(0.001)$ & $(0.007)$ & $(0.002)$ & $(0.001)$ & $(0.002)$ \\
\hline \multirow[t]{2}{*}{ CF vol. } & $0.125^{* * *}$ & $0.802^{* * *}$ & $0.128^{* * *}$ & 0.031 & $0.084^{* * *}$ \\
\hline & $(0.033)$ & $(0.199)$ & $(0.049)$ & $(0.040)$ & $(0.030)$ \\
\hline \multirow[t]{2}{*}{ EPU } & $-0.019^{* * *}$ & $-0.127^{* * *}$ & $-0.013^{* * *}$ & 0.003 & $0.006^{* *}$ \\
\hline & $(0.004)$ & $(0.042)$ & $(0.004)$ & $(0.003)$ & $(0.003)$ \\
\hline \multirow[t]{2}{*}{ cons } & $0.672^{* * *}$ & 0.714 & $0.675^{* * *}$ & $0.015^{* * *}$ & $0.011^{* *}$ \\
\hline & $(0.079)$ & $(0.554)$ & $(0.108)$ & $(0.005)$ & $(0.005)$ \\
\hline Firm FE & $\mathrm{Y}$ & $\mathrm{Y}$ & $\mathrm{Y}$ & $\mathrm{N}$ & $\mathrm{N}$ \\
\hline $\mathrm{N}$ & 37424 & 37194 & 21471 & 32757 & 18541 \\
\hline R-sq & 0.145 & 0.116 & 0.151 & 0.147 & 0.165 \\
\hline
\end{tabular}

Notes: The dependent variable is the 1 percent winsorized (Cash + Short-Term Investment)/Asset ratio in level, log, and first difference (FD). Columns 3 and 5 excludes US firms. All regressions include country and year fixed effects, in addition to firm fixed effects in columns 1-3. Standard errors in parenthesis are clustered at the firm level. Profit is defined as cash flow in percent of total assets and nws stands for net working capital. Source: Thompson Reuters Worldscope. 
Table 5: Non-missing $R \& D$ sample only

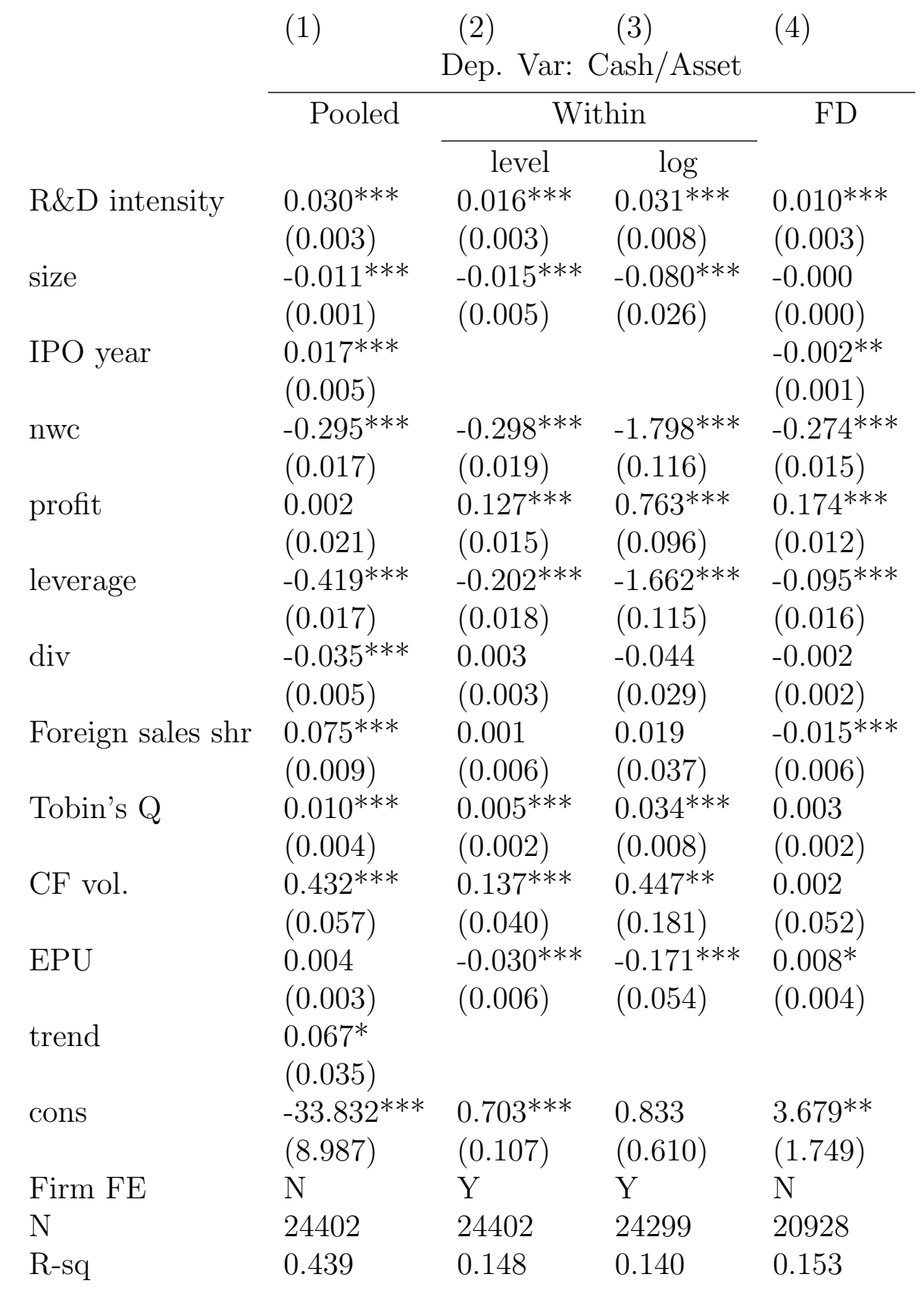

Notes: The dependent variable is the 1 percent winsorized (Cash + Short-Term Investment)/Asset ratio in level, log, and first difference (FD). Only observations with non-missing, non-negative $R \& D$ expenditure are included in the regressions. All regressions include country and year fixed effects, in addition to firm fixed effects in columns 2-3. Profit is defined as cash flow in percent of total assets and nws stands for net working capital. Standard errors in parenthesis are clustered at the firm level. Source: Thompson Reuters Worldscope.

51

CInternational Monetary Fund. Not for Redistribution 
Table 6: Controlling for tax motive

(1)

Pooled

level

\begin{tabular}{|c|c|c|c|c|c|}
\hline & level & level & $\begin{array}{l}\text { Dep. Var: } \\
\log \end{array}$ & $\begin{array}{l}\text { Cash ratio in } \\
\text { level: } \\
\text { non-missing } \mathrm{R} \& \mathrm{D}\end{array}$ & $\begin{array}{l}\text { level: } \\
\text { no foreign asset }\end{array}$ \\
\hline R\&D intensity & $\begin{array}{l}\mathbf{0 . 3 2 5} \text { *** } \\
(0.054)\end{array}$ & $\begin{array}{l}\mathbf{0 . 0 3 9} * * \\
(0.016)\end{array}$ & $\begin{array}{l}\mathbf{0 . 1 7 4} * * * \\
(0.062)\end{array}$ & $\begin{array}{l}\mathbf{0 . 0 1 8} * * * \\
(0.006)\end{array}$ & $\begin{array}{l}\mathbf{0 . 0 4 1} * * \\
(0.018)\end{array}$ \\
\hline size & $\begin{array}{l}-0.010^{* * *} \\
(0.001)\end{array}$ & $\begin{array}{l}-0.021^{* * *} \\
(0.003)\end{array}$ & $\begin{array}{l}-0.117^{* * *} \\
(0.024)\end{array}$ & $\begin{array}{l}-0.025^{* * *} \\
(0.004)\end{array}$ & $\begin{array}{l}-0.003 \\
(0.006)\end{array}$ \\
\hline IPO year & $\begin{array}{l}0.009^{* * *} \\
(0.003)\end{array}$ & & & & \\
\hline nwc & $\begin{array}{l}-0.201^{* * *} \\
(0.013)\end{array}$ & $\begin{array}{l}-0.280^{* * *} \\
(0.015)\end{array}$ & $\begin{array}{l}-1.799^{* * *} \\
(0.108)\end{array}$ & $\begin{array}{l}-0.333^{* * *} \\
(0.019)\end{array}$ & $\begin{array}{l}-0.333^{* * *} \\
(0.036)\end{array}$ \\
\hline profit & $\begin{array}{l}0.058^{* * *} \\
(0.021)\end{array}$ & $\begin{array}{l}0.138^{* * *} \\
(0.013)\end{array}$ & $\begin{array}{l}1.301^{* * *} \\
(0.102)\end{array}$ & $\begin{array}{l}0.143^{* * *} \\
(0.016)\end{array}$ & $\begin{array}{l}0.073^{* * *} \\
(0.023)\end{array}$ \\
\hline leverage & $\begin{array}{l}-0.344^{* * *} \\
(0.012)\end{array}$ & $\begin{array}{l}-0.180^{* * *} \\
(0.011)\end{array}$ & $\begin{array}{l}-1.680^{* * *} \\
(0.098)\end{array}$ & $\begin{array}{l}-0.186^{* * *} \\
(0.015)\end{array}$ & $\begin{array}{l}-0.239^{* * *} \\
(0.021)\end{array}$ \\
\hline div. status & $\begin{array}{l}-0.014^{* * *} \\
(0.004)\end{array}$ & $\begin{array}{l}0.003 \\
(0.003)\end{array}$ & $\begin{array}{l}-0.019 \\
(0.026)\end{array}$ & $\begin{array}{l}0.003 \\
(0.004)\end{array}$ & $\begin{array}{l}-0.006 \\
(0.005)\end{array}$ \\
\hline Share of foreign sales & $\begin{array}{l}0.067^{* * *} \\
(0.006)\end{array}$ & $\begin{array}{l}0.007 \\
(0.006)\end{array}$ & $\begin{array}{l}0.110^{* *} \\
(0.047)\end{array}$ & $\begin{array}{l}0.006 \\
(0.007)\end{array}$ & $\begin{array}{l}0.067^{* * *} \\
(0.024)\end{array}$ \\
\hline ETR & $\begin{array}{l}-0.018 * * * \\
(0.006)\end{array}$ & $\begin{array}{l}-\mathbf{0 . 0 0 8} * * \\
(0.004)\end{array}$ & $\begin{array}{l}-\mathbf{0 . 0 5 8} \\
(0.033)\end{array}$ & $\begin{array}{l}-\mathbf{0 . 0 0 7} \\
(0.005)\end{array}$ & $\begin{array}{l}-\mathbf{0 . 0 1 3} \\
(0.008)\end{array}$ \\
\hline Tobin's Q & $\begin{array}{l}0.015^{* * *} \\
(0.002)\end{array}$ & $\begin{array}{l}0.005^{* * *} \\
(0.001)\end{array}$ & $\begin{array}{l}0.041^{* * *} \\
(0.007)\end{array}$ & $\begin{array}{l}0.004^{* *} \\
(0.002)\end{array}$ & $\begin{array}{l}0.002 \\
(0.002)\end{array}$ \\
\hline CF vol. & $\begin{array}{l}0.509^{* * *} \\
(0.058)\end{array}$ & $\begin{array}{l}0.164^{* * *} \\
(0.035)\end{array}$ & $\begin{array}{l}1.244^{* * *} \\
(0.301)\end{array}$ & $\begin{array}{l}0.157^{* * *} \\
(0.042)\end{array}$ & $\begin{array}{l}0.128^{* *} \\
(0.054)\end{array}$ \\
\hline EPU index & $\begin{array}{l}0.011^{* * *} \\
(0.002)\end{array}$ & $\begin{array}{l}-0.018^{* * *} \\
(0.004)\end{array}$ & $\begin{array}{l}-0.157^{* * *} \\
(0.039)\end{array}$ & $\begin{array}{l}-0.026^{* * *} \\
(0.006)\end{array}$ & $\begin{array}{l}-0.009 \\
(0.009)\end{array}$ \\
\hline Country FE & $\mathrm{Y}$ & $\mathrm{Y}$ & $\mathrm{Y}$ & $\mathrm{Y}$ & $\mathrm{Y}$ \\
\hline Year FE & $\mathrm{Y}$ & $\mathrm{Y}$ & $\mathrm{Y}$ & $\mathrm{Y}$ & $\mathrm{Y}$ \\
\hline Firm FE & $\mathrm{N}$ & $\mathrm{Y}$ & $\mathrm{Y}$ & $\mathrm{Y}$ & $\mathrm{Y}$ \\
\hline $\mathrm{N}$ & 29712 & 38430 & 38176 & 24273 & 10817 \\
\hline R-sq & 0.400 & 0.152 & 0.128 & 0.158 & 0.156 \\
\hline
\end{tabular}

(2)

(3)

Within
(4)

Notes: The dependent variable is the 1 percent winsorized (Cash + Short-Term Investment)/Asset ratio in level or log. Only observations with non-missing, non-negative $R \& D$ expenditure are included in column 4, and only firm-year observations with zero foreign assets are included in column 5. ETR stands for the effective tax rate in percent of as described in the text. Profit is defined as cash flow in percent of total assets and nws stands for net working capital. Standard errors in parenthesis are clustered at the firm level. Source: Thompson Reuters Worldscope. 
Table 7: Net lending regressions

Pooled

$(1)$

\begin{tabular}{ll} 
Within-firm \\
\hline \\
\cline { 3 - 4 }$(2)$ & (3) non-missing R \& D sample
\end{tabular}

Dependent Variable: Net Lending/Sales

$R \& D$ intensity $_{t}$

$\mathbf{0 . 2 1 9} * * * \quad-0.032$

$(0.033) \quad(0.059)$

$R \& D$ intensity $_{t+1}$

$R \& D$ intensity $_{t+2}$

size

IPO year

$0.002^{* * *}$

0.003

(0.003)

0.008

0.012

$0.039 * * *$

$0.048^{* * *}$

(0.021)

$(0.010)$

(0.011)

0.034*

$0.027 * * *$

$0.032^{* *}$

(0.007)

$(0.020)$

$(0.010)$

0.002

$0.023^{* * *}$

$(0.014)$

$0.029^{* * *}$

$0.050 * *$

(0.001)

(0.003)

(0.003)

(0.004)

(0.022)

$0.044^{* * *}$

0.001

$(0.003)$

nwc

$0.020^{* * *}$

profit

(0.006)

$0.062^{* * *}$

$0.024^{* * *}$

$-0.000$

$0.030^{* * *}$

$0.042^{* *}$

$0.063^{* *}$

$(0.009)$

(0.009)

(0.009)

$0.148^{* * *} \quad-0.005$

$0.166^{* * *}$

$(0.017)$

$0.197^{* * *}$

(0.027)

$(0.021)$

leverage

$-0.068^{* * *}$

(0.020)

(0.003)

(0.014)

(0.022)

$0.214^{* * *}$

$(0.009)$

$-0.059^{* * *}$

$-0.092^{* * *}$

$-0.065^{* * *}$

$-0.080^{* * *}$

(0.031)

$-0.024^{* * *}$

(0.009)

(0.010)

(0.010)

(0.016)

$-0.075^{* * *}$

div. status

$(0.003)$

Share of foreign sales

$0.014^{* * *}$

(0.003)

$-0.034^{* * *}$

$-0.033^{* * *}$

$-0.046^{* * *}$

(0.024)

(0.003)

(0.003)

(0.003)

(0.006)

$-0.052^{* * *}$

(0.005)

Tobin's Q

$0.010^{* * *}$

(0.007)

0.006

$-0.001$

$-0.009$

(0.010)

(0.008)

(0.006)

(0.009)

$-0.007$

$0.003^{* * *}$

$0.004^{* * *}$

$0.003^{* * *}$

0.001

$(0.016)$

(0.001)

(0.001)

(0.001)

(0.001)

$(0.001)$

0.001

CF vol.

0.047

0.005

$-0.002^{* * *}$

0.051

$-0.007$

(0.001)

(0.043)

EPU index

0.003

(0.039)

(0.001)

(0.031)

(0.042)

0.010

0.003

(0.004)

(0.003)

ETR

Country FE

Year FE

Firm FE

$\mathrm{N}$

Y

$\mathrm{Y}$

$\mathrm{N}$

30144

R-sq

0.121

$\mathrm{Y}$
$\mathrm{Y}$
$\mathrm{Y}$

39019

0.037

$-0.080 * * *$
$(0.004)$
$\mathrm{Y}$
$\mathrm{Y}$
$\mathrm{Y}$

Y

$-0.165^{* * *}$
$(0.013)$

$-0.195^{* * *}$

(0.023)

$\mathrm{Y} \quad \mathrm{Y}$

Y $\quad Y$

Y Y

36796

21722

10869

5578

0.026

0.105

0.107

0.110

Notes: The dependent variable is the 1 percent winsorized Net Lending/Sales ratio where Net Lending is defined as

Net Lending $=$ Net Income + Depreciation - Dividend paid - Capital Expenditure. Only observations with non-missing, non-negative $R \& D$ expenditure are included in columns 4-6. Col. 5-6 includes firms in the top half and top quintile of profitability (net margin) respectively. ETR stands for the effective tax rate as described in the text. Profit is defined as cash flow in percent of total assets and nws stands for net working capital. Standard errors in parenthesis are clustered at the firm level. Source: Thompson Reuters Worldscope. 
Table 8: Controlling for share buyback

\begin{tabular}{|c|c|c|c|c|c|c|}
\hline \multirow[b]{3}{*}{$R \& D$ intensity $_{t}$} & \multicolumn{3}{|c|}{ Cash ratio } & \multicolumn{3}{|c|}{ Net lending } \\
\hline & \multirow{2}{*}{$\begin{array}{l}\text { Pooled } \\
\mathbf{0 . 3 2 4}^{* * *} \\
(0.054)\end{array}$} & \multicolumn{2}{|c|}{ Within } & \multirow{2}{*}{$\begin{array}{l}\text { Pooled } \\
\mathbf{0 . 2 0 6}^{* * *} \\
(0.034)\end{array}$} & \multicolumn{2}{|c|}{ Within } \\
\hline & & $\begin{array}{l}\mathbf{0 . 0 1 8} \text { *** } \\
(0.006)\end{array}$ & $\begin{array}{l}\mathbf{0 . 0 1 8} * * \\
(0.009)\end{array}$ & & & \\
\hline$R \& D$ intensity $_{t+1}$ & & & & & $\begin{array}{l}\mathbf{0 . 0 1 3} \\
(0.011)\end{array}$ & $\begin{array}{l}\mathbf{0 . 0 4 7} * * * \\
(0.008)\end{array}$ \\
\hline$R \& D$ intensity $_{t+2}$ & & & & & $\begin{array}{l}\mathbf{0 . 0 2 6}^{* *} \\
(0.011)\end{array}$ & $\begin{array}{l}\mathbf{0 . 0 4 9}^{* *} \\
(0.022)\end{array}$ \\
\hline size & $\begin{array}{l}-0.010^{* * *} \\
(0.001)\end{array}$ & $\begin{array}{l}-0.025^{* * *} \\
(0.004)\end{array}$ & $\begin{array}{l}-0.024^{* * *} \\
(0.005)\end{array}$ & $\begin{array}{l}0.002^{* * *} \\
(0.001)\end{array}$ & $\begin{array}{l}0.023^{* * *} \\
(0.003)\end{array}$ & $\begin{array}{l}0.046^{* * *} \\
(0.008)\end{array}$ \\
\hline IPO year & $\begin{array}{l}0.009^{* * *} \\
(0.003)\end{array}$ & & & $\begin{array}{l}0.001 \\
(0.003)\end{array}$ & & \\
\hline nwc & $\begin{array}{l}-0.201^{* * *} \\
(0.013)\end{array}$ & $\begin{array}{l}-0.333^{* * *} \\
(0.019)\end{array}$ & $\begin{array}{l}-0.332^{* * *} \\
(0.021)\end{array}$ & $\begin{array}{l}0.023^{* * *} \\
(0.006)\end{array}$ & $\begin{array}{l}0.032^{* * *} \\
(0.009)\end{array}$ & $\begin{array}{l}0.064^{* *} \\
(0.027)\end{array}$ \\
\hline profit & $\begin{array}{l}0.053^{* *} \\
(0.021)\end{array}$ & $\begin{array}{l}0.143^{* * *} \\
(0.016)\end{array}$ & $\begin{array}{l}0.144^{* * *} \\
(0.016)\end{array}$ & $\begin{array}{l}0.068^{* * *} \\
(0.022)\end{array}$ & $\begin{array}{l}0.167^{* * *} \\
(0.014)\end{array}$ & $\begin{array}{l}0.213^{* * *} \\
(0.032)\end{array}$ \\
\hline leverage & $\begin{array}{l}-0.344^{* * *} \\
(0.012)\end{array}$ & $\begin{array}{l}-0.186^{* * *} \\
(0.016)\end{array}$ & $\begin{array}{l}-0.168^{* * *} \\
(0.017)\end{array}$ & $\begin{array}{l}-0.066^{* * *} \\
(0.009)\end{array}$ & $\begin{array}{l}-0.069^{* * *} \\
(0.010)\end{array}$ & $\begin{array}{l}-0.087^{* * *} \\
(0.025)\end{array}$ \\
\hline div. status & $\begin{array}{l}-0.014^{* * *} \\
(0.004)\end{array}$ & $\begin{array}{l}0.003 \\
(0.004)\end{array}$ & $\begin{array}{l}0.003 \\
(0.004)\end{array}$ & $\begin{array}{l}-0.021^{* * *} \\
(0.003)\end{array}$ & $\begin{array}{l}-0.033^{* * *} \\
(0.003)\end{array}$ & $\begin{array}{l}-0.053^{* * *} \\
(0.010)\end{array}$ \\
\hline Share of foreign sales & $\begin{array}{l}0.067^{* * *} \\
(0.006)\end{array}$ & $\begin{array}{l}0.006 \\
(0.007)\end{array}$ & $\begin{array}{l}-0.000 \\
(0.009)\end{array}$ & $\begin{array}{l}0.012^{* *} \\
(0.005)\end{array}$ & $\begin{array}{l}-0.001 \\
(0.006)\end{array}$ & $\begin{array}{l}-0.006 \\
(0.016)\end{array}$ \\
\hline ETR & $\begin{array}{l}-0.018^{* * *} \\
(0.006)\end{array}$ & $\begin{array}{l}-0.007 \\
(0.005)\end{array}$ & $\begin{array}{l}-0.004 \\
(0.005)\end{array}$ & $\begin{array}{l}-0.073^{* * *} \\
(0.005)\end{array}$ & $\begin{array}{l}-0.079^{* * *} \\
(0.004)\end{array}$ & $\begin{array}{l}-0.187^{* * *} \\
(0.023)\end{array}$ \\
\hline Tobin's Q & $\begin{array}{l}0.016^{* * *} \\
(0.002)\end{array}$ & $\begin{array}{l}0.004^{* *} \\
(0.002)\end{array}$ & $\begin{array}{l}0.005^{* * *} \\
(0.002)\end{array}$ & $\begin{array}{l}0.010^{* * *} \\
(0.001)\end{array}$ & $\begin{array}{l}0.004^{* * *} \\
(0.001)\end{array}$ & $\begin{array}{l}0.001 \\
(0.001)\end{array}$ \\
\hline CF vol. & $\begin{array}{l}0.508^{* * *} \\
(0.058)\end{array}$ & $\begin{array}{l}0.157^{* * *} \\
(0.042)\end{array}$ & $\begin{array}{l}0.155^{* * *} \\
(0.048)\end{array}$ & $\begin{array}{l}0.021 \\
(0.040)\end{array}$ & $\begin{array}{l}0.045 \\
(0.035)\end{array}$ & $\begin{array}{l}0.011 \\
(0.043)\end{array}$ \\
\hline EPU index & $\begin{array}{l}0.011^{* * *} \\
(0.002)\end{array}$ & $\begin{array}{l}-0.025^{* * *} \\
(0.006)\end{array}$ & $\begin{array}{l}-0.023^{* * *} \\
(0.006)\end{array}$ & $\begin{array}{l}0.004 \\
(0.004)\end{array}$ & & \\
\hline buyback $_{t}$ & $\begin{array}{l}\mathbf{0 . 1 4 6}^{* * * *} \\
(0.031)\end{array}$ & $\begin{array}{r}\mathbf{- 0 . 0 0 4} \\
(0.036)\end{array}$ & $\begin{array}{l}\mathbf{0 . 0 0 1} \\
(0.036)\end{array}$ & $\begin{array}{l}\mathbf{0 . 1 3 5}^{* * * *} \\
(0.026)\end{array}$ & $\begin{array}{l}\mathbf{0 . 0 4 6} \text { ** } \\
(0.019)\end{array}$ & $\begin{array}{l}\mathbf{0 . 1 1 5} \text { **** } \\
(0.039)\end{array}$ \\
\hline buyback $_{t+1}$ & & & $\begin{array}{l}\mathbf{0 . 1 1 7} * * * \\
(0.034)\end{array}$ & & $\begin{array}{l}\mathbf{0 . 0 3 2}^{* *} \\
(0.016)\end{array}$ & $\begin{array}{r}\mathbf{- 0 . 0 1 6} \\
(0.040)\end{array}$ \\
\hline buyback $_{t+2}$ & & & $\begin{array}{l}\mathbf{0 . 0 6 0}^{* *} * \\
(0.023)\end{array}$ & & $\begin{array}{l}\mathbf{0 . 0 2 5}^{*} \\
(0.013)\end{array}$ & $\begin{array}{l}\mathbf{0 . 0 2 6} \\
(0.033)\end{array}$ \\
\hline $\mathrm{N}$ & 29708 & 24269 & 19929 & 29654 & 21547 & 5529 \\
\hline R-sq & 0.401 & 0.158 & 0.159 & 0.142 & 0.108 & 0.112 \\
\hline
\end{tabular}

Notes: The variables are defined as in Tables 3 to 7 . The new variable buyback is defined as the percent change in the amount of ordinary shares outstanding when there was a reduction and zero otherwise. All regressions include country and year fixed effects. Except for columns 1 and 4, all regressions include firm fixed effects. The within regressions only include firms with non-missing R\&D spending. Column 6 is run on sub-sample of firms with the highest profitability, i.e. net margin above 9 percent (corresponding to 75 percentile). Profit is defined as cash flow in percent of total assets and nws stands for net working capital. 


\section{References}

Adler, K., Ahn, J., and Dao, M. C. (2017). Corporate cash holding and innovation in the era of globalization. IMF Working Paper, forthcoming.

André, C., Guichard, S., Kennedy, M., and Turner, D. (2007). Corporate net lending.

Aoyagi, C. and Ganelli, G. (2014). Unstash the cash! corporate governance reform in Japan. IMF Working Paper, 14/140.

Armenter, R. and Hnatkovska, V. (2017). Taxes and capital structure: Understanding firms savings. Journal of Monetary Economics, 87:13-33.

Autor, D., Dorn, D., Hanson, G. H., Pisano, G., Shu, P., et al. (2016). Foreign competition and domestic innovation: Evidence from US patents. NBER Working Paper No. 22879.

Autor, D., Dorn, D., Katz, L. F., Patterson, C., and Van Reenen, J. (2017). Concentrating on the fall of the labor share.

Azar, J., Kagy, J.-F., and Schmalz, M. C. (2016). Can changes in the cost of carry explain the dynamics of corporate cash holdings? Review of Financial Studies, 29(8):2194-2240.

Bacchetta, P. and Benhima, K. (2015). The demand for liquid assets, corporate saving, and international capital flows. Journal of the European Economic Association, 13(6):1101-1135.

Barkai, S. (2016). Declining labor and capital shares. Stigler Center for the Study of the Economy and the State New Working Paper Series, (2).

Bates, T. W., Chang, C. H., and Chi, J. D. (2016). Why has the value of cash increased over time?

Bates, T. W., Kahle, K. M., and Stulz, R. M. (2009). Why do us firms hold so much more cash than they used to? The journal of finance, 64(5):1985-2021.

Begenau, J. and Palazzo, B. (2016). Firm selection and corporate cash holdings. Harvard Business School Finance Working Paper, (16-130).

Behringer, J. and van Treeck, T. (2018). Income distribution and the current account. Journal of International Economics, 114:238-254.

Bloom, N., Draca, M., and Van Reenen, J. (2016). Trade induced technical change? the impact of chinese imports on innovation, it and productivity. The Review of Economic Studies, 83(1):87-117.

Booth, L. D. and Zhou, J. (2013). Increase in cash holdings: Pervasive or sectorspecific? Frontiers in Finance and Economics, (10(2), 31-64). 
Chen, P., Karabarbounis, L., and Neiman, B. (2017). The global rise of corporate saving. Journal of Monetary Economics.

Dao, M. C., Das, M., Koczan, Z., and Lian, W. (2017). Why is labor receiving a smaller share of global income? Theory and empirical evidence. IMF Working Paper No. 17/169.

Dao, M. C., Hanisch, I., Jones, C., and Li, N. (2018). The granularity of corporate saving. IMF Working Paper, forthcoming.

De Loecker, J. and Eeckhout, J. (2017). The rise of market power and the macroeconomic implications.

Della Seta, M. (2011). Cash and competition.

Dittmar, A., Mahrt-Smith, J., and Servaes, H. (2003). International corporate governance and corporate cash holdings. Journal of Financial and Quantitative analysis, 38(1):111-133.

Dittmar, A. K. (2000). Why do firms repurchase stock. The Journal of Business, $73(3): 331-355$.

Döttling, R., Ladika, T., and Perotti, E. C. (2016). The (self-) funding of intangibles.

Falato, A., Kadyrzhanova, D., and Sim, J. (2013). Rising intangible capital, shrinking debt capacity, and the US corporate savings glut. FEDS No. 2013-6\%.

Fan, J. and Kalemli-Özcan, Ş. (2016). Emergence of asia: Reforms, corporate savings, and global imbalances. IMF Economic Review, 64(2):239-267.

Foley, C. F., Hartzell, J. C., Titman, S., and Twite, G. (2007). Why do firms hold so much cash? a tax-based explanation. Journal of Financial Economics, 86(3):579607.

Gao, H., Harford, J., and Li, K. (2013). Determinants of corporate cash policy: Insights from private firms. Journal of Financial Economics, 109(3):623-639.

Graham, J. R. and Leary, M. T. (2016). The evolution of corporate cash.

Graham, J. R. and Leary, M. T. (2017). The evolution of corporate cash. NBER Working Paper No. $2376 \%$.

Gruber, J. and Kamin, S. B. (2016). The corporate saving glut and falloff of investment spending in oecd economies. IMF Economic Review, 64(4):777-799.

Gutiérrez, G. and Philippon, T. (2017). Investment-less growth: An empirical investigation. Brookings Papers on Economic Activity.

IMF (2006). Awash with cash: Why are corporate savings so high? World Economic Outlook. 
IMF (2017). External sector report. International Monetary Fund.

Johansson, Å., Skeie, Ø. B., Sorbe, S., and Menon, C. (2017). Tax planning by multinational firms. OECD Economics Department Working Paper No. 1355.

Lyandres, E. and Palazzo, B. (2016). Cash holdings, competition, and innovation. Journal of Financial and Quantitative Analysis, 51(6):1823-1861.

Ma, L., Mello, A. S., and Wu, Y. (2014). Industry competition, winner's advantage, and cash holdings.

Markle, K. S. and Shackelford, D. A. (2012). Cross-country comparisons of corporate income taxes. National Tax Journal, 65(3):493.

Miller, M. H. and Orr, D. (1966). A model of the demand for money by firms. The Quarterly journal of economics, 80(3):413-435.

Morellec, E., Nikolov, B., and Zucchi, F. (2014). Competition, cash holdings, and financing decisions.

Olley, G. S. and Pakes, A. (1992). The dynamics of productivity in the telecommunications equipment industry.

Pinkowitz, L., Stulz, R. M., and Williamson, R. (2015). Do us firms hold more cash than foreign firms do? The Review of Financial Studies, 29(2):309-348.

Poterba, J. M., Hall, R. E., and Hubbard, R. G. (1987). Tax policy and corporate saving. Brookings Papers on Economic Activity, 1987(2):455-515.

Zucman, G. (2014). Taxing across borders: Tracking personal wealth and corporate profits. The Journal of Economic Perspectives, 28(4):121-148. 


\section{Appendix A - Figures}

Figure 16: Decomposing change in gross saving rates into sources - year by year.
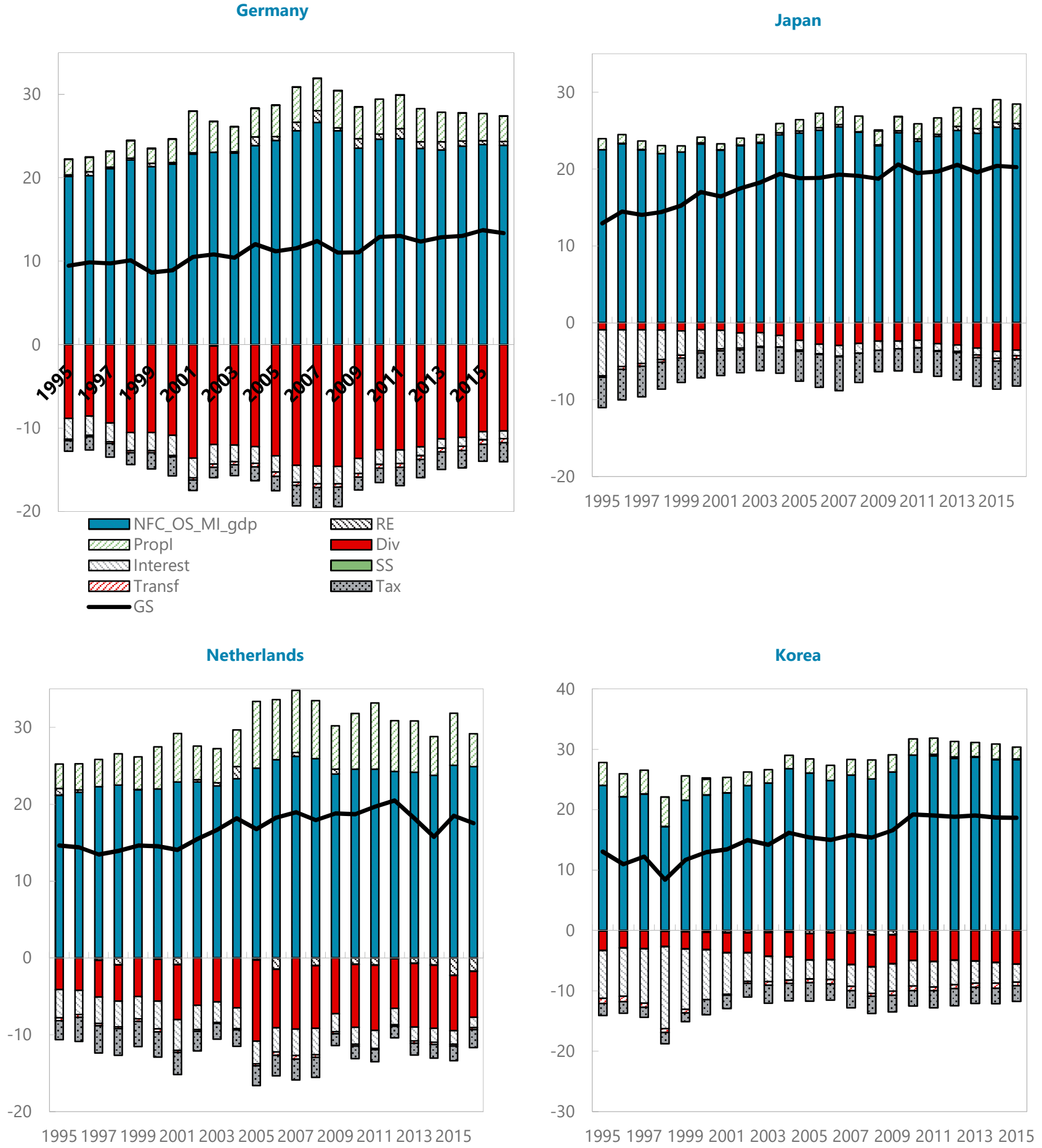

Source: OECD, National Sources and IMF Staff calculations. 
Table 9: Count of Unique Firm ID by Sector in Each Country

$\begin{array}{ccccccccc}\text { Canada } & \text { France } & \text { Germany } & \text { Japan } & \text { Italy } & \text { Korea } & \text { Netherlands } & \text { UK } & \text { USA } \\ 16 & 13 & 6 & 1 & 11 & 1 & 9 & 23 & 37 \\ 745 & 19 & 15 & 6 & 17 & 9 & 7 & 166 & 501 \\ 27 & 25 & 29 & 9 & 356 & 21 & 90 & 97 & 133 \\ 482 & 566 & 574 & 208 & 2079 & 116 & 1481 & 853 & 3250 \\ 106 & 66 & 55 & 42 & 218 & 20 & 59 & 157 & 564 \\ 60 & 81 & 61 & 12 & 412 & 27 & 78 & 140 & 350 \\ 74 & 81 & 53 & 14 & 573 & 16 & 43 & 256 & 613 \\ 299 & 373 & 279 & 52 & 963 & 73 & 244 & 850 & 2198\end{array}$




\section{Appendix C - Macro Data Sources}

The Appendix describes the sources of macro data used in the analysis.

\section{Aggregate Data}

To build the aggregate dataset we combined different sources.

\section{Income Accounts}

Data on Net Lending, Gross saving and Capital Expenditure by institutional sectors are gathered from the following sources:

- Canada: Data come from Statistics Canada, the Canadian Statistical Office. We used the information contained in the Current and Capital Account by Sector, with particular reference to sectoral gross saving and net lending. http:// www5. statcan.gc.ca/cansim/a45?lang=eng\&childId=37641032\&CORId=3764\&preState= 1\&childIds $=37641044 ; 37641053 ; 37641054 ; 37641055 ; 37641058 ; 37641055 ; 37641054$; $37641053 ; 37641053 ; 37641059 ; 37641045 ; 37641047 ; 37641032 ; 37641033$; 37641035 ; 37641036 ; 37641037 ; 37641034 ; 37641034 ; 37641035 ; 37641037 ; 37641036 ; 37641033 ; $37641054 ; 37641048 ; 37641049 ; 37641047$; 37641055;37641045;37641044;

- Japan: Data come from the National Accounts of Japan - Income and Outlay Accounts classified by Institutional Sectors as gathered by the Japanese Cabinet Office. http://www.esri.cao.go.jp/en/sna/data/kakuhou/files/ 2014/28annual_report_e.html\#c1

- South Korea: Data come from the National Account - Production, Income and Capital Accounts - Income Accounts by Institutional Sectors provided by the Bank of Korea. http://ecos.bok.or.kr/flex/EasySearch_e.jsp

- USA: Data come from the Financial Accounts of the USA, as gathered by the Federal Reserve. http://www. federalreserve.gov/datadownload/Review. aspx?rel=Z1\&series=bf 046 beec 7 deaa3609bed122971a339\&lastobs=\&from= 01/01/1970\&to=12/31/2016\&filetype=csv\&label=include\&layout=seriescolumn

- France, Germany, Italy, Netherlands, UK: Data come from Eurostat, Quarterly Sector Accounts; Non-financial transactions. http://ec.europa. eu/eurostat/data/database.

Whenever possible, we provide a decomposition of Gross saving in Profits and Distributed Income. Moreover, we further decompose Profits in Gross Operating Surplus, Interest, Rent, Taxes, Other Transfers. The most detailed account of these variables is provided by the OECD in the Detailed National Accounts, SNA 2008: Non-financial accounts by sectors, annual (Edition 2015), which comprises statistics on the whole set of financial accounts in terms of production accounts, generation of income accounts, allocation of primary income accounts, use of disposable income account, 
change in net worth due to saving and capital transfer accounts and acquisitions of non-financial assets accounts. Data is expressed in national currency current prices.

\section{Flow of Funds Data}

We refer to the Financial Account to collect information on how the surplus or deficit of the capital account is financed by transactions in financial assets and liabilities. The financial account indicates how net borrowing sectors obtain resources by incurring liabilities or reducing assets, and how net lending sectors allocate their surpluses by acquiring assets or reducing liabilities. Financial flows represent the difference between the opening financial balance sheet at the start of the year and the closing balance sheet at the end of the year. Financial stocks, as registered in balance sheets at a given point in time, are the result of the accumulation of financial flows over time. We focus on the Financial Stocks. Our balance-sheet data are provided by:

- Statistics Canada: National Balance Sheet Accounts by Sector, available at http: //www5 . statcan .gc . ca/cansim/a45?lang=eng\&childId=37641025\&CORId= 3764\&preState=1\&childIds=37641023;

- Eurostat: ("Financial flows and stocks" - France, Germany, Italy, Netherlands, UK) http://ec .europa.eu/eurostat/data/database?p_p_id=NavTreeportletprod_ WAR_NavTreeportletprod_INSTANCE_nPqeVbPXRmWQ\&p_p_lifecycle=0\&p_p_state= normal\&p_p_mode=view\&p_p_col_id=column-2\&p_p_col_count=1

- the Federal Reserve: we downloaded the balance sheet data on nonfinancial corporations as described in the table B103 at the following link: http://www . federalreserve.gov/releases/Z1/current/z1.pdf. Data are downloaded from this link: http://www. federalreserve.gov/datadownload/Choose. aspx? rel=Z1.

- the Bank of Korea: http://ecos.bok.or.kr/flex/EasySearch_e.jsp

- the Bank of Japan: http://www.stat-search.boj.or.jp/ssi/cgi-bin/famecgi2? cgi=\$nme_a000_en\&lstSelection $=11 \$ 1$

We construct variables as follows:

\section{- Liquid Assets}

- Canada

* Currency and deposits

* Short-term debt securities

* Investment fund shares

- Countries in Eurostat

* Currency and deposits (F2)

* Short-term debt securities (F31) 
* Investment fund shares (F52)

- Japan

* Currency and deposits

- Currency

- Transferable deposits

- Time and saving deposits

- Certificates of deposits

- Foreign currency deposits

* Short-term debt

- Treasure discount bills

- Central government securities and FILP bonds

- Local government securities

- Public corporation securities

- Bank debentures

- Industrial securities

- External securities issued by residents

- Commercial paper

- Investment trust beneficiary certificates

- Trust beneficiary rights

- Structured-financing instruments

* Short-term loans

- Repurchase agreements and securities lending transactions (liquid sub-category of loans)

- Call loans and bills (liquid sub-category of loans)

- Korea

* Currency and deposits

* Short-term debt

- Government bonds

- Financial debentures

- Commercial papers

- USA

* Currency and Deposits

* Short-term debt: "Nonfinancial corporate business; debt securities; asset"

* Liquid Shares

- Money market fund shares

- Repo

- Accounts Receivables

62

(C)International Monetary Fund. Not for Redistribution 
- Countries in Eurostat

* Accounts receivables (F8): Trade credits and advances and other accounts receivables

- Japan

* Trade credits and foreign trade credits

- Korea

* Trade credits

- USA

* Trade receivables

\section{- Financial Debt}

- We subtract the value of equity liabilities from the value of Total Financial Liabilities. 